\title{
ESCRIBIR LA HISTORIA DE LA ARQUITECTURA EN LA ESPAÑA DE LAS LUCES
}

\author{
Writing the bistory of architecture in Spanish \\ Enlightenment
}

\author{
Daniel CRESPO DELGADO \\ Fundación Juanelo Turriano \\ danielcrespodelgado@hotmail.com
}

Fecha de recepción: 10/01/2016

Fecha de aceptación definitiva: 25/07/2016

RESUMEN: Tomando como referencia un amplio y variado elenco de fuentes, se analizan los valores que en la España de la Ilustración se utilizaron para explicar el desarrollo y la evolución de la arquitectura. Entendida como una manifestación más de la civilización, el relato de su historia se vinculó al de otros ámbitos y bebió de principios propios de la Ilustración, sobre todo de la moderada, revelando los límites rupturistas del pensamiento artístico español.

Palabras clave: Historiografía de la arquitectura; Historiografía del arte; Jovellanos; Juan Agustín Ceán Bermúdez; Antonio Ponz.

ABSTRACT: Having considered a wide array of sources of information, this paper explores the values that were used to explain the development of architecture during the Enlightenment in Spain. At that time, architecture was considered just another expression of civilization. Its history was connected to other fields and was directly inspired by Enlightenment values, especially moderation, which revealed the limits to ground-breaking Spanish artistic thought.

Key words: History of architectural historiography; art historiography; Jovellanos; Juan Agustín Ceán Bermúdez; Antonio Ponz. 
Dar a luz una historia del arte. Tal fue un anhelo reiterado en la España de la segunda mitad del siglo XVIII y principios del XIX. Reiterado e inédito puesto que nunca antes se había afirmado con tal claridad e intención programática. Un objetivo nuevo, por tanto, y estrechamente vinculado a las aspiraciones que recorrieron el periodo. De hecho, fue habitual plantearlo como una tarea más de las que cabía emprender para restaurar el perdido pulso del país. El pasado de las bellas artes también se contó entre las ocupaciones de la Ilustración.

Esta clamada historia de las artes se adecuaba bien a la nueva historiografía que pugnaba por imponerse bajo el signo de las Luces. Un impulsor de la renovación historiográfica como fue Jovellanos censuró a los cronistas modernos que no incluían referencias a las bellas artes en sus obras. Su consideración de disciplinas de alto valor y significado cultural las convertía, en opinión de Jovellanos, en merecedoras de integrarse en el relato del estado y la evolución de una sociedad ${ }^{1}$. En 1812, Juan Agustín Ceán Bermúdez leyó un discurso en la Academia de la Historia como presentación de una versión de su introducción a las Noticias de los arquitectos y arquitectura de España. Ante este auditorio, justificó su labor en la que sería la primera historia de la arquitectura española cuando se publicó en 1829, señalando que Jovellanos, su mentor, le había recomendado no apartarse jamás

de la historia de las bellas artes españolas... pues teniendo este ramo mucha conexión con la general de España, si llegas a desempeñarle con acierto, podrás ser útil a la misma Academia, y ayudar a que llene el gran objeto de su instituto ${ }^{2}$.

Sin embargo, aun su predicada relevancia, tal Historia estaba sin hacer. En su exitoso Viaje de España (1772-1794), Antonio Ponz ya había arremetido contra la escasa e inadecuada información que hasta la fecha se tenía sobre el patrimonio artístico del país. Censuró el limitado interés de la literatura tradicional por dar a conocer artistas y monumentos, mientras se habían llenado páginas y más páginas con descripciones de vanas batallas o insulsas reliquias. Pero no menos lamentó que los pocos que se habían preocupado por las bellas artes hubiesen caído por lo general en vacíos ditirambos y noticias dudosas. A lo largo de los 18 tomos de su Viaje, Ponz ofreció un gran cúmulo de datos y juicios pretendidamente precisos sobre tales disciplinas y los monumentos de su pasado. No obstante, fue consciente de que no estaba dando a la luz una historia del arte, de que proporcionaba materiales pero no levantaba el anhelado edificio, una tarea que esperaba que se acometiese con presteza ${ }^{3}$. Su sucesor en la secretaría de la Real Academia de

1. Según Jovellanos, «el origen y progresos de las bellas artes eran un indicio harto seguro de la cultura de los pueblos". Jovellanos, Gaspar Melchor de. "Descripción de la catedral de Palma». En Jovellanos. Memorias histórico-artísticas de arquitectura. Madrid: Akal, 2013, p. 257. Edición a cargo de Daniel Crespo Delgado y Joan Domenge Mesquida.

2. Biblioteca Nacional de España, Ms. 21456 (7).

3. Crespo Delgado, Daniel. Un viaje para la Ilustración. El Viaje de España (1772-1794) de Antonio Ponz. Madrid: Marcial Pons, 2012. 
Bellas Artes de San Fernando y en la realización de viajes artísticos, Isidoro Bosarte, afirmó de igual modo su decidida intención de bucear en archivos y recurrir a colaboradores para compilar noticias con las que elaborar una "historia de las bellas artes en España ${ }^{4}$. Llegó incluso a proclamar este objetivo, como algún que otro contemporáneo, desde la prensa periódica 5 . Parecía distinguirse, por tanto, no sólo un nuevo interés respecto a la consideración y estudio del pasado del arte, sino también entre la mera recopilación de noticias y la configuración de un relato histórico propiamente dicho. La definición de cómo debía componerse dicho relato se hizo en paralelo a la de otros ámbitos que también dieron forma a la Historia de las Luces.

Los hermanos Rodríguez Mohedano advirtieron que su Historia literaria de España desde su primera población hasta nuestros dias (1766-1791) se alejaba de las meras bibliotecas, de la colección libresca, y pretendía establecer el "origen, progresos, decadencia, causas, revoluciones y varios estados de las ciencias" ${ }^{6}$. En su Elogio de las Bellas Artes (1781), Jovellanos enunció un objetivo similar: "Pintar el inmenso cuadro que representa el destino de las artes desde su origen hasta el presente estado", desvelando "la serie de causas que han influido otras veces en su elevación o su ruina» ${ }^{7}$. Jovellanos leyó este Elogio en la junta pública de la Academia de San Fernando celebrada el 14 de julio de 1781. Aun su limitada extensión, propia de un discurso académico, el Elogio puede considerarse una de las primeras historias del arte español puesto que Jovellanos consiguió trazar una visión global de la evolución de las bellas artes en el país; de sus "progresos, decadencia» y "varios estados" si echamos mano de la terminología de la época. Un par de décadas después, Ceán publicó su enjundioso Diccionario histórico de los más ilustres profesores de las Bellas Artes en España (1800), una obra estrechamente vinculada al Elogio y que nacía de unas mismas inquietudes. Subrayó Ceán las abundantes noticias que había reunido de pintores, escultores, miniaturistas, grabadores, plateros, rejeros e «imagineros en vidrio y bordado». Las daría a conocer en forma de diccionario, ordenadas

4. BosaRTE, Isidoro. Viage artístico a varios pueblos de España con el juicio de las obras de las tres nobles artes que en ellas existen y épocas á que pertenecen. Madrid: Imprenta Real, 1804, p. III.

5. Crespo Delgado, Daniel. "Diario de Madrid 1787-1788: de cuando la historia del arte español devino una cuestión pública». Goya, 2007, 319-320, pp. 246-259.

6. Rodríguez Mohedano, Rafael y Pedro. Historia literaria de España, desde su primera población hasta nuestros días. Origen, progresos, decadencia y restauración de la literatura española. Madrid: v. i., 1766-1791, t. I, p. CI. Sobre esta obra: CEBRIÁN, José. "La Historia literaria de España de los Mohedano: concepto, finalidad y primeros reparos». Cuadernos de Estudios del Siglo XVIII, 1992, 2, pp. 57-71.

7. Jovellanos, Gaspar Melchor de. Elogio de las bellas artes. Madrid: Casimiro, 2014, p. 99. Esta edición cuenta con un sugestivo estudio introductorio: PORTús, Javier. "Jovellanos: una historia moral de la pintura española», pp. 7-43. El Elogio se publicó por vez primera en la Distribución de los premios concedidos por el Rey Nuestro Señor á los discípulos de las Nobles Artes, hecha por la Academia de San Fernando. Madrid: Joaquín Ibarra, 1781, pp. 35-102. 
alfabéticamente por artistas, con lo que la narración histórica se desdibujaba. Sin embargo, confesó que su aspiración última había sido escribir tal "historia analítica de las artes españolas»; si no lo había hecho en esta ocasión y había optado por otra fórmula era, sobre todo, por verse sin el tiempo suficiente para realizar empresa tan compleja, resultándole más fácil disponer alfabéticamente los datos de los artistas ${ }^{8}$. Se escudó arguyendo que en la introducción de su Diccionario, de unas 25 páginas, había puesto «los cimientos de esta grande obra» al plantear los principios de la evolución en España de «la pintura, la escultura y otras bellas artes dimanadas del dibujo e imitadoras de la naturalezan?.

No acometería en parte esta "gran obra" hasta unos años después, en su monumental Historia del Arte de la Pintura (1822-1828), donde expuso las etapas y consecuciones de las principales escuelas pictóricas europeas ${ }^{10}$. En 1829 publicaría la ya citada Noticias de los arquitectos y arquitectura en España, una obra iniciada por Eugenio Llaguno en la década de los años 60 y que legó a Ceán a su muerte, en 1799, para que la continuase. Ceán la continuó y la enriqueció con abundantes referencias, pero también reforzando su carácter narrativo. En el discurso preliminar de la obra, Ceán estableció diez épocas que dividían la arquitectura española desde sus orígenes hasta su actualidad. Tales periodos revelaban la variación de las formas de la arquitectura, "sus alteraciones", causadas, según sus propias palabras, "unas veces por los usos y costumbres" de las naciones que dominaron la Península, otras "por la ignorancia y capricho de los artistas»" ${ }^{11}$ Razones históricas y artísticas, por tanto, explicaban los cambios en las bellas artes. Las propias Noticias, las páginas dedicadas al comentario de autores y edificaciones, se estructuraron cronológicamente por épocas que se iniciaban con una introducción donde se exponían sus rasgos generales. Los comentarios de los arquitectos y monumentos incluidos en cada una de estas edades ilustraron en numerosas ocasiones dichos rasgos y la evolución del periodo. No era la primera vez que Ceán ensayaba este formato puesto que en su Descripción artística de la catedral de Sevilla (1804) proporcionó «una historia completa» del templo hispalense organizando sus noticias en los periodos históricos que habían marcado su construcción. Los encargados de examinar este trabajo por encargo de la Academia de la Historia y la de San Fernando resaltaron como uno de sus máximos méritos haber descrito las obras según la época a la que pertenecían, así como «su tino en derivar

8. Cé́n Bermúdez, Juan Agustín. Diccionario historico de los mas ilustres profesores de las bellas artes en España. Madrid: Imprenta de la Viuda de Ibarra, 1800 t. I, pp. XXXIII-XXXIV.

9. CEÁN, Diccionario..., op. cit., t. I, pp. XXXIV-XXXV.

10. La tradicional infravaloración de esta Historia debe revisarse: Crespo Delgado, Daniel y García López, David. "Ceán Bermúdez y la Historia del Arte de la Pintura. En CeÁn Bermúdez, Juan Agustín. Historia del Arte de la Pintura en España. Oviedo: KRK, 2016, pp. 11-213.

11. Llaguno Amírola, Eugenio. Noticias de los arquitectos y arquitectura de España desde su restauración..., ilustradas y acrecentadas con notas, adiciones y documentos por D. Juan Agustín Cean-Bermudez. Madrid: Imprenta Real, 1829, t. I, p. XIV. 
las variaciones de la arquitectura de las causas y de los hechos, y de los profesores que han influido en cada revolución del arte» ${ }^{12}$.

El acercamiento al pasado de las bellas artes, por tanto, no sólo pretendía acumular datos fidedignos y juicios precisos pero aislados sobre la calidad de las obras. Su intención era ordenarlas y colocarlas en un fresco que explicase sus transformaciones. Partiendo de una concepción del pasado como una sucesión de momentos estelares y críticos, se afirmó que el relato histórico debía exponer los principios que permitían a las artes alcanzar su plenitud o explicar su caída, mostrando así las circunstancias en las que se desarrollaban o declinaban. Esto hacía que la Historia pudiese proporcionar decisivas lecciones para el presente, siendo un privilegiado instrumento para la defensa de un determinado ideario estético, el neoclásico. De ahí que, por un lado, la historia del arte fuese apoyada por las instituciones -en especial la Real Academia de San Fernando- y los círculos empeñados en definir un renovado lenguaje artístico. No obstante, el fulgor de dicha disciplina se proyectaba más allá.

En su Ensayo de una historia civil de España (1794), Vicente González Arnao insistió en el carácter formativo que tenía el adecuado relato del pasado, el promovido por la Ilustración, alejado de ruidosos pero inanes hechos de armas o cortesanos, y centrado en una renovada comprensión del devenir de las sociedades. Se refirió a la división de la Historia en varias ramas y a la utilidad sectorial de cada una de ellas. Las distintas profesiones podían hallar "lecciones ejemplares acomodadas a sus respectivas situaciones»: así, el jurisconsulto descubriría los resultados de las diversas legislaciones y los motivos de su variedad; el militar, los adelantamientos de la táctica; el político, las causas y efectos de las revoluciones de los Estados, etc. Sin embargo, González Arnao advirtió que las ramas de la Historia no estaban desunidas, influyéndose de manera recíproca y conformando un todo orgánico: «las revoluciones políticas producen otras en la religión, cultura, legislación y comercio, y mutuamente éstas influyen infinitas veces en aquéllas» ${ }^{13}$. Por tanto, las lecciones a extraer de ellas también rebasaban un campo limitado, desvelando las «revoluciones» -y algunas de sus causas- por las que habían pasado no ya tal o cual saber, sino las propias naciones.

En su Elogio de Ventura Rodríguez (1788), Jovellanos presentó al arquitecto madrileño como el restaurador del buen gusto tras la debacle churrigueresca. Afirmó que Rodríguez había suplido la falta de un viaje a Roma, epicentro de la definida como modélica arquitectura, con una lección mayor: había estudiado los "progresos y vicisitudes" de los monumentos españoles. "Instruido por la enseñanza y el escarmiento de las edades pasadas», Ventura Rodríguez había logrado

12. Archivo de la Academia de Historia, Exp. CBC75 (agradezco a la investigadora Miriam Cera que me diera a conocer este documento); Biblioteca Nacional de España, Ms. 21458(11)

13. GonzÁlez Arnao, Vicente. Ensayo de una historia civil de España. Madrid: Benito Cano, 1794, p. 7 
desentrañar los correctos principios de la arquitectura y por consiguiente liderar su regeneración ${ }^{14}$. En opinión del prócer asturiano, el viaje por la Historia podía sustituir e incluso superar al de Roma; no había mejor lección posible. El propio Jovellanos aprovechó este discurso y sus notas para plantear una evolución de la arquitectura española y analizar algunas de sus etapas más problemáticas como la irrupción del gótico o la crisis barroca. De todo ello creyó que se extraían lecciones preciosas para las bellas artes, pero también de otra naturaleza. Subrayó que los edificios, aun en ruinas, ilustraban "la historia de la cultura o la ignorancia de innumerables generaciones ${ }{ }^{15}$. De los argumentos de Jovellanos se deducía que, visualizando la sucesión de monumentos a lo largo de las edades, uno podía tener la misma sensación que Voltaire frente al incesante ir y venir del mar al que se refirió al inicio de su Filosofía de la Historia (1765): todo cambiaba, el hombre se alzaba y caía; la Historia, al menos la conformada desde principios bien asentados, la que aseveró escrita por y para filósofos, debía permitir entender tales vaivenes ${ }^{16}$. Desde este punto de vista, podríamos decir que las artes y su pasado caían ya bajo la jurisdicción del "filósofo", de quien perseguía comprender, no siendo únicamente motivo de interés para los facultativos o profesionales de las mismas. El propio Voltaire recurrió a las bellas artes en sus muy influyentes obras historiográficas para demostrar o ejemplificar algunas de sus tesis. Constatamos que las Luces tuvieron la pretensión de escribir una historia del arte y le otorgaron un inédito papel y lugar.

\section{1. "El BUEN O MAL GUSTO CAMINA ENTRE LAS COSAS A UN MISMO PASO"}

Los autores y trabajos citados hasta aquí muestran que los anhelos historiográfico-artísticos no quedaron en la nómina de los proyectos irrealizados del periodo. Se publicaron diversas obras y, añadámoslo, de enjundia. La posterioridad ha reconocido la importancia de tales aportaciones. La generación ilustrada proclamó un objetivo, lo consolidó como necesaria tarea cultural y acumuló trabajos que lo concretaban o que, al menos, ayudaban a su realización. Los distintos formatos ensayados, desde artículos en la prensa periódica a eruditos diccionarios,

14. Jovellanos, Gaspar Melchor de. Elogio de D. Ventura Rodríguez leido en la Real Sociedad de Madrid... en la junta ordinaria del sábado 19 de enero de 1788... Madrid: Imprenta de la viuda de Ibarra, 1790, p. 34. Lo cierto es que Ventura Rodríguez conoció y estuvo decisivamente influido por la Roma barroca, que conocería a través de tratados y estampas: RoDRíGuEz RuIz, Delfín. "De viajes de estampas de arquitectura en el siglo XVIII. El Studio d'Architettura Civile de Domenico de Rossi y su influencia en España». Boletín de Arte, 2013, 34, pp. 247-296. Su interés por la historia de la arquitectura española, o al menos por alguno de sus capítulos, en especial por Herrera, se constata a través de diversas fuentes: CRESPO. Un viaje..., op. cit.

15. Jovellanos. Elogio de D. Ventura Rodríguez..., op. cit., p. 15.

16. Voltaire. Filosofía de la Historia. Madrid: Tecnos, 1990. Edición a cargo de Martín Caparrós. 
también tendrían un gran futuro ${ }^{17}$. De hecho, podríamos considerar la historia del arte como uno de los ámbitos de la renovación historiográfica promovida por las Luces que produjo frutos más destacados.

Los escritos de Ponz, Bosarte, Jovellanos o los resultados de la inagotable labor de Ceán Bermúdez son todavía consultas inexcusables para el historiador del arte. Estos autores citaron y describieron múltiples obras, desempolvaron archivos, recuperaron fuentes y movilizaron a una extensa red de colaboradores por todo el país que permitió la obtención de numerosas noticias sobre artistas y monumentos. A pesar de la indudable contribución de obras barrocas -descuella ante todo el Parnaso Español, Pintoresco y Laureado (1724) de Antonio Palomino- ${ }^{18}$ se consiguió aportar el primer gran acervo de noticias sobre el pasado artístico del país ${ }^{19}$. Se recopilaron, pero de igual modo se ordenaron y se historiaron, cumpliendo así con los horizontes pretendidos. En tales trabajos la Historia se trazó desde los valores característicos de las Luces. Resulta pertinente, por tanto, hablar de una historia del arte de la Ilustración. No hubo una narración única aunque en líneas generales se compartieron aspectos decisivos como las etapas por las que había transcurrido el arte español, su caracterización y las causas de su eclosión y decaimiento. De ahí que sea posible (y creemos que revelador) exponer tal relato.

En el discurso preliminar de las Noticias, Ceán afirmó que los romanos habían traído a España las modélicas artes de los griegos. Pero su importación no había sido epidérmica y, en escaso tiempo, "las adaptaron los españoles, y se igualaron en el arte a sus maestros ${ }^{20}$. Subrayó seguidamente que maestros y discípulos, romanos e hispanos, levantaron numerosos y espléndidos monumentos por toda la Península. Había recopilado sus restos «en una penosa y prolija obra» titulada Sumario de las antigüedades romanas de España pertenecientes a las bellas artes. Aunque la había presentado a la Academia de la Historia y fue aprobada en 1818, todavía no había visto la luz. Esperaba que lo hiciese tras la publicación de las Noticias por considerarla complementaria, su necesario preludio (advirtamos que las Noticias se iniciaron en el siglo VIII, tras la conquista árabe de la Península). Sus esperanzas se cumplieron, aunque con algo de retraso, ya fallecido su autor. Sea

17. ÚBEDA DE los CoBos, Andrés. «La prehistoria de la historia del arte». En Historiografía del arte español en los siglos XIX y XX. Madrid: Alpuerto, pp. 125-137.

18. El Parnaso se publicó como tercera parte de El Museo Pictórico y Escala Óptica (1715-1724). A pesar de que Palomino fue censurado por los ilustrados por la falta de criticismo en sus datos y juicios, lo utilizaron enormemente. De hecho, culminando un proyecto largamente acariciado, se reeditó en 1797 por la Academia de San Fernando. Véanse los ejemplares trabajos de Miguel Morán, Bonaventura Bassegoda y especialmente: ÚBEDA DE LOS CoBos, Andrés. Pensamiento artístico español del siglo XVIII. De Antonio Palomino a Francisco de Goya. Madrid: Museo del Prado, 2001.

19. La aportación de Ceán Bermúdez es paradigmática en este sentido: SANTiago PÁEz, Elena (com.). Ceán Bermúdez, historiador del arte y coleccionista ilustrado. Madrid: Biblioteca Nacional de España, CEEH, 2016.

20. Llaguno, Noticias..., op. cit., t. I, p. XVII. 
como fuere, en el Sumario (1832), Ceán volvió a insistir en el esplendor alcanzado por la arquitectura en España bajo la dominación romana:

...construyeron aquí habitaciones para su comodidad, almacenes para su comercio, fortalezas para su defensa, templos para el culto de sus númenes, espectáculos para sus diversiones, y otros suntuosos edificios para la administración de justicia, para la educación de la juventud, y para otros usos de la policía agraria, civil y militar ${ }^{21}$.

Fue igual de entusiasta en su Historia del Arte de la Pintura (1822-1828), donde incluyó dos capítulos dedicados a los mosaicos y la cerámica hispanorromana $^{22}$. Si bien admitió que eran pocas las cerámicas, pintadas o no, conservadas íntegramente, los fragmentos encontrados en diversas localidades eran en cambio numerosos, testimoniando su gran difusión. De hecho, lo que Juan Agustín quería mostrar con estos dos capítulos era, una vez más, el rico patrimonio romano de la Península; que Hispania no sólo participó de los adelantos del Imperio y de su predicada extraordinaria cultura, sino que contribuyó a su engrandecimiento. Los restos de mosaicos y cerámicas probaban, según Ceán, «el lujo y magnificencia que había en este reino cuando le dominaban los romanos", así como la afición que existía "por todo género de pintura»" Esta reivindicación del patrimonio artístico nacional fue una constante, y ya no sólo de una época tan admirada como la Antigüedad, sino de prácticamente todas.

Enlazando con un lugar común y tradicional en la historiografía de la Edad Moderna, la caída del Imperio Romano supuso a los ojos de los ilustrados el inicio de un periodo de decadencia generalizado, que también había afectado a las artes. La irrupción de los llamados bárbaros y la inestabilidad política consiguiente habían sepultado el gusto, los buenos modelos y la misma afición por lo artístico. Las bellas artes decayeron porque, en definitiva, dejaron de cultivarse e interesar. Jovellanos escribió que «la época de la dominación de los Septentrionales no tiene arquitectura propia ${ }^{24}$. Según el prócer asturiano, este periodo mostraba, como se constataba de nuevo en los territorios cristianos tras la conquista de los árabes, lo que el filósofo Adam Ferguson en su An Essay on the history of civil Society (1767) había advertido: pueblos cuya dedicación principal era la guerra no se ocupaban de las artes ${ }^{25}$. Lo artístico se presentó como un rasgo del progreso de la civilización. Sin embargo, valorando de manera positiva Jovellanos algunos aspectos de la actividad de los visigodos tras su asentamiento en la Península, sobre todo su labor legislativa, una faceta elogiada en general por la Ilustración, negó el carácter

21. CEÁn Bermúdez, Juan Agustín. Sumario de las antigüedades romanas que hay en España, en especial las pertenecientes a las Bellas Artes. Madrid: Imprenta de Miguel de Burgos, Prefacio, p. II.

22. Ceán Bermúdez, Juan Agustín. Historia del Arte de la Pintura. Archivo de la Real Academia de Bellas Artes de San Fernando, 377-387/3, t. I, pp. 77-89 y 95-103 respectivamente.

23. Ibidem, t. I, 89.

24. Jovellanos. Elogio de D. Ventura Rodríguez..., op. cit., p. 85.

25. Ibidem, p. 22. 
meramente destructor que se les solía achacar. Aunque en su Elogio de Ventura Rodríguez (1790) dudó que se conservasen edificios de su época, gracias a sus viajes posteriores por el norte de Castilla pudo comprobar que no era as ${ }^{26}$. En esta misma línea, Ceán calificó a los visigodos en su Historia de la Pintura como «algo más civilizados que los demás invasores» de la Península ${ }^{27}$. Dedicó palabras positivas a su organización del Estado y de la Iglesia a través de los concilios toledanos -era comprensible que un ilustrado viese con buenos ojos la colaboración de la Iglesia con el Estado- hasta el punto de que les atribuyó «el restablecimiento de las artes» tras su ocaso, un fenómeno que puso en paralelo al de su adopción de la religión católica. Si bien no predicó de ellas ni de su decoración ningún mérito artístico, citó sobre todo a través de fuentes escritas algunas de las iglesias que levantaron los visigodos. Ni siquiera en tan crítico momento las bellas artes en España parecían haber desaparecido por completo.

En las Noticias Ceán fue claro: los árabes habían supuesto un avance puesto que construyeron "todo género de edificios con más arte e inteligencia que los godos ${ }^{28}$. Lo atribuyó a su sólido asentamiento en gran parte del reino y a su mayor instrucción «en las matemáticas y en otras ciencias y artes». Citó algunas de las extraordinarias obras que las fuentes antiguas describían y otras que todavía se conservaban, en especial en Sevilla y Granada. Incluso no dejó de aseverar cierto florecimiento cultural vivido en esta época, escribiendo "que no había ciudad alguna en España durante la dominación árabe en que no hubiese grandes maestros, que enseñaban ciencias, artes y literatura ${ }^{29}$. Con esta afirmación, que creaba un apropiado contexto para situar sus monumentos, Ceán se hacía eco de las cada vez más numerosas, si bien no exentas de disputas, vindicaciones de las aportaciones andalusies. En ellas, las alusiones a sus producciones artísticas no quedaron al margen y no fueron inocentes. José Nicolás de Azara censuró que viajeros como Henry Swinburne -quien describió, estudió y grabó la Alhambra y la mezquita de Córdoba en 1779- elogiasen a "los moros, a su historia y su arquitectura", no con otra intención que «humillar» a los españoles al comparar el desarrollo del país bajo su égida con su actual postración ${ }^{30}$. La lectura promovida por los españoles de este legado y que, sin ir más lejos, detectamos en Ceán, era completamente diferente: España había sido el refugio de las luces en una Europa sumida en la oscuridad.

26. Barón Thaidigsmann, Javier. Ideas de Jovellanos sobre arquitectura. Oviedo: Principado de Asturias, 1985.

27. CEÁn. Historia..., op. cit., t. I, p. 278.

28. Llaguno. Noticias..., op. cit., t. I, p. XXII.

29. Llaguno. Noticias..., op. cit., t. I, p. XXIX.

30. La carta de Azara se publicó en la 2. ${ }^{a}$ edición (1782) de la Introduccion a la Historia Natural y a la Geografía Física de España de Guillermo Bowles, y parte de ella en el prólogo del tomo I del Viage fuera de España (1785) de Antonio Ponz. Para Swinburne ver Pérez BerEnguel, José Francisco. "La figura de Henry Swinburne y las características de su Viaje por España». Cuadernos Dieciochistas, 2008, 9, pp. 211-228. 
Para mantener cierta caracterización displicente de un enemigo tradicional como eran los árabes, pero acudiendo a ellos para afianzar el maltrecho prestigio nacional, Jovellanos utilizó un recurso que no era nuevo y tendría un largo recorrido: distinguir entre la feracidad y rudeza de los primeros árabes coetáneos a Mahoma, y los cultivados que les sucedieron, de manera especial de quienes se instalaron en la península Ibérica ${ }^{31}$. Lo afirmó Jovellanos poco después de que apareciese el primer tomo de las Antigüedades Árabes de España (1787-1804), una lujosa empresa promovida por la Academia de San Fernando donde se reunieron una serie de excepcionales estampas sobre la Alhambra y la mezquita de Córdoba, dos de los monumentos que visualizaban sus sorprendentes edificaciones ${ }^{32}$. Antes de su impresión, se encontraron dos posiciones respecto a las Antigüedades. Una, encarnada precisamente por Jovellanos, defendió el interés de que la publicación diese pie a un apropiado análisis artístico de tales construcciones pues podría esclarecer, por ejemplo, la formación del gótico; la otra sólo supo justificarla por razones de prestigio institucional y gubernamental: se podía imprimir porque era un trabajo hecho, esperado y sobre un legado propio pero que por desgracia ya había sido dado a conocer por un extranjero, Swinburne ${ }^{33}$.

A pesar de que la segunda opción fuese a la postre la que decidió la publicación de las Antigüedades, cuestiones historiográficas como el origen del gótico no fueron una cuestión trivial para la generación ilustrada. El propio Jovellanos lo abordó en las notas del Elogio de Ventura Rodríguez (1790) y algunos años antes lo hizo Bosarte en las páginas del Gabinete de Lectura Española (1787-1793) ${ }^{34}$. Conocedor como pocos de las inquietudes eruditas europeas, el jesuita Juan Andrés en sus Cartas familiares (1786-1791) señaló que España, con variados testimonios arquitectónicos árabes en su territorio, era un lugar adecuado para dilucidar el origen del gótico. Se partía de la idea de que el gótico era una arquitectura nueva que de algún modo había sido influenciada por la también heterodoxa arquitectura árabe. Andrés afirmó que si tal análisis llegase a buen término, acarrearía un gran honor a los españoles por haber resuelto una duda que «hasta ahora [los sabios] no han podido averiguar ${ }^{35}$. No exageraba puesto que tal era un asunto debatido en el continente. De hecho, hubo quien viajó por España para estudiar, principalmente, sus edificios medievales ${ }^{36}$.

31. Jovellanos. Elogio de D. Ventura Rodríguez..., op. cit., pp. 88 y ss.

32. El análisis más ajustado sobre esta obra se encuentra en RODRíGUEZ RUIZ, Delfín. La memoria frágil. José de Hermosilla y las Antigüedades Árabes de España. Madrid: COAM, 1992.

33. CREspo. Un viaje..., op. cit.; El legado de al-Ándalus. Las antigüedades árabes en los dibujos de la Academia. Madrid: Real Academia de Bellas Artes de San Fernando, 2015.

34. Crespo y Domenge. Jovellanos..., op. cit.

35. ANDrés, Juan. Cartas familiares del Abate D. Juan Andrés a su hermano D. Carlos Andrés. Madrid: Antonio Sancha, 1786-1791, t. II, p. 29, nota 1.

36. Mateo SEvilla, Matilde. "En busca del origen del gótico: el viaje de Thomas Pitt por España en 1760». Goya, 2003, 292, pp. 9-23. 
Todo ello revela un inédito interés por la arquitectura bajomedieval. Partiendo de propuestas lanzadas por la erudición francesa barroca ${ }^{37}$, en la segunda mitad del siglo XVIII se generalizó la división de la arquitectura medieval en el denominado gótico antiguo y moderno. Las imponentes estructuras del gótico moderno, definidas por su elevación y decoración, no sólo se admiraron, también se predicó de ellas un carácter totalmente nuevo. Antonio Ponz afirmó que nada tenían que ver con las apocadas, sencillas y robustas estructuras del precedente gótico antiguo (que podríamos identificar a grandes rasgos con el románico), propias de una sociedad guerrera, sumida en un violento pulso por la supervivencia ${ }^{38}$. Jovellanos subrayó en sus elogios de las bellas artes y de Ventura Rodríguez que la irrupción del gótico reflejaba los profundos cambios que se estaban produciendo en la sociedad, las letras y las ciencias contemporáneas: "La arquitectura sintió también esta revolución „39. Para el asturiano, la arquitectura gótica encarnaba un mundo que se despertaba tras siglos de letargo. Su conocida vinculación con las cruzadas partió de esta idea. Basándose en The History of the Reign of the Emperor Charles V(1769) de William Robertson, entendió las cruzadas como el primer gran hito que permitió a Europa surgir de las tinieblas en las que se hallaba desde la caída de Roma; las presentó como un elocuente movimiento de un mundo que volvía a la vida.

Por supuesto, Jovellanos defendió la participación de los reinos cristianos peninsulares en las cruzadas y de arquitectos españoles en las expediciones militares, que en Oriente encontraron la inspiración espiritual y formal para crear la nueva arquitectura gótica ${ }^{40}$. España no podía quedar al margen de un fenómeno artístico tan significativo. En las Noticias de los arquitectos y arquitectura de España (1829) Ceán no sólo retomó la tesis de Jovellanos de las cruzadas, sino que insistió en "el poder e influjo» de este género de arquitectura en el propio país. Sus catedrales medievales, subrayó, nada tenían que envidiar a las europeas más extraordinarias ${ }^{41}$. Llevando este discurso a su última expresión, otro asturiano ligado a Jovellanos, Juan Miguel de Inclán Valdés, publicó en 1833 unos Apuntes para la bistoria de la arquitectura y observaciones sobre la que se distingue con la denominación de Gótica, donde defendió la primacía de España en el origen y desarrollo de la arquitectura gótica moderna ${ }^{42}$.

37. Calatrava, Juan. Arquitectura y cultura en el Siglo de las Luces. Granada: Universidad de Granada, 1999.

38. CRespo. Un viaje..., op. cit.

39. Jovellanos. Elogio de D. Ventura Rodríguez..., op. cit., p. 24

40. CRespo y Domenge. Jovellanos..., op. cit.

41. LlagunO. Noticias..., op. cit., t. I, pp. XXXIV y XXXV.

42. Jovellanos es la principal autoridad de los Apuntes del arquitecto Inclán Valdés, siendo citado permanentemente, de manera elogiosa e incluso expresando su autor su estima personal por el prócer gijonés (Apuntamientos..., pp. 48 y 61). Sobre Inclán, su obra y su tiempo: Calatrava, Juan. "La construcción romántica de la historia de la arquitectura española, 1829-1848». En CALATRAVA, Juan 
Si para una parte de la erudición ilustrada o de la formada en sus principios, las cruzadas habían sido un decisivo fermento para la nueva arquitectura gótica, la aparición de sus sorprendentes construcciones siempre se vinculó a un contexto de cambio, apertura y avance de las que, recordémoslo, las cruzadas se entendieron como uno de sus más relevantes fenómenos. Desde Cataluña, Antonio de Campmany convirtió los edificios «de la Baja Edad que se conservan en la ciudad de Barcelona» en testimonio del modélico y anhelado desarrollo alcanzado por la ciudad en el Medioevo ${ }^{43}$. En sus Memorias histórico-artísticas de arquitectura (1806-1808), Jovellanos también presentó las principales construcciones góticas de Palma de Mallorca como un símbolo del periodo más brillante de la isla ${ }^{44}$. No deja de ser significativo que el propio Jovellanos, entre los fenómenos del siglo XIII que en España revelaban el nacimiento de una nueva época, destacase la aparición de un "sabio legislador", Alfonso X, quien no sólo había protegido distintas ciencias, sino que había producido un "código admirable [las Partidas], que será perpetuo testimonio de los progresos del espíritu humano en aquel tiempo" ${ }^{45}$. Los elementos que conformaban la civilización -y el regalismo lo era para un ilustrado moderado como Jovellanos- se movían al unísono. Precisamente, en una de las obras que exaltaban la labor de Fernando III y de Alfonso X, consagrado como prototipo de rey absoluto por la Ilustración cortesana ${ }^{46}$, las Memorias para la vida del Santo Rey Don Fernando III redactada por Andrés Marcos Burriel y dadas a luz con apéndices y otras ilustraciones por D. Miguel de Manuel Rodríguez (1800), se publicó un retrato de Fernando III a partir de una pintura conservada en el convento de San Clemente de Sevilla. Este cuadro, que se dijo realizado bajo el reinado de su sucesor Alfonso X, fue citado por Ceán Bermúdez en su Historia del Arte de la Pintura (1822-1828) como prueba del nuevo aliento que las artes plásticas también fueron tomando en España a partir del siglo XIII ${ }^{47}$. Historia y bellas artes aparecían estrechamente vinculadas.

Aun desarrollándose un interés erudito y hasta estético por ciertos periodos y producciones medievales, el siglo XVI siguió considerándose el momento decisivo de la modernidad para las bellas artes. De ahí que despertara una inclinación prioritaria. Se manifestaría, por ejemplo, cuando nuestros estudiosos hallaron artistas u obras que esclarecían esta etapa. No hubo hallazgo más entusiasmante para Bosarte en sus periplos castellanos que dar con el nombre del restaurador

(ed.). Romanticismo y arquitectura. La historiografía arquitectónica en la España de mediados del siglo XIX. Madrid: Abada, 2011, pp. 13-52.

43. Grau, Ramon y López, Marina. "Origen de la revaloració del gòtic a Barcelona: Capmany, 1792». Quaderns d'Història, 2003, 8, pp. 143-177.

44. Crespo y Domenge. Jovellanos..., op. cit.

45. Jovellanos. Elogio de las bellas..., op. cit., p. 49.

46. Villacañas Berlanga, José Luis. «Una idea y escritura de la Historia en la conciencia nacional del siglo XVIII». Cuadernos Dieciochistas, 2013, 14, pp. 19-57.

47. Ceán. Historia..., op. cit., t. I, p. 300. 
del acueducto de Segovia bajo los Reyes Católicos al considerarlo el primero en retomar la gramática clásica ${ }^{48}$.

Como una ya larga tradición había afianzado, la predicada restauración del buen gusto bajo el Renacimiento se había producido en Italia. Ceán llegó a apuntar que en España se habían dado las mismas circunstancias para protagonizar tal revolución, pero fue en Florencia y Roma donde se llevó a cabo ${ }^{49}$. Eso sí, se aseguró que España se había sumado al renacer artístico con un entusiasmo y unos resultados inigualables. En su Discurso sobre la restauracion de las Bellas Artes en España (1787), Bosarte subrayó la temprana atención que los españoles mostraron por este retorno de las artes a su debida senda. Según Bosarte, fueron tantas las obras pictóricas ejecutadas en España durante este periodo y tan aventajadas, que no hubo nación que siguiese más de cerca los nuevos caminos abiertos en la Península vecina ${ }^{50}$. En su Diccionario histórico (1800), Ceán subrayó que en la España del siglo XVI hubo artistas notables en múltiples ámbitos, tanto que, a reserva de Italia, "en ningún otro de Europa [las bellas artes] estuvieron tan adelantadas" ${ }^{51}$.

Entre tantos destellos, fueron las perfecciones que según los ilustrados se alcanzaron en la arquitectura las que merecieron un mayor detenimiento. De este modo, dicha disciplina, que por su carácter público se dijo que tenía una especial relevancia, encarnó el admirable periodo abierto en el siglo XVI. Esto permitió satisfacer distintos objetivos. Desde mediados del XVIII, fueron varios los artífices y mandatarios vinculados a la Real Academia de Bellas Artes de San Fernando que presentaron El Escorial como el mejor de los edificios españoles y una necesaria inspiración para superar una crisis, que se aseguró la arquitectura sufría contemporáneamente por culpa de la «secta churrigueresca». Tal como ha escrito Delfín Rodríguez, El Escorial se convirtió en un "contrapunto de lo barroco" ${ }^{52}$. Aunque partiendo de tales corrientes, el Viaje de España (1772-1794) de Antonio Ponz supuso una contribución decisiva para la exaltación ilustrada de El Escorial; de quien se consideró su principal responsable, Juan de Herrera, y, no menos importante, del propio periodo ${ }^{53}$. En el Viaje se dieron a conocer noticias inéditas sobre Herrera, se le atribuyeron proyectos por toda España y se creó un verdadero corpus de su obra, encumbrándose su labor junto a la de toda una amplia nómina de arquitectos que pasaron a conformar la juzgada como la más brillante época del arte nacional. La consideración del siglo XVI como Siglo de Oro del

48. BOSARTE. Viage..., op. cit.

49. CEÁn. Historia..., op. cit., t. VI, pp. 3 y ss.

50. Bosarte, Isidoro. Discurso sobre la restauracion de las Bellas Artes en España (1787). En Gabinete de Lectura Española. Madrid: Imprenta de la viuda de Ibarra, Hijos y Compañía, 1787-1793, papel n. ${ }^{\circ}$.

51. CEÁn. Diccionario..., op. cit., t. I, p. XLVI.

52. RODRíguez Ruiz, Delfín. "La sombra de un edificio: El Escorial en la cultura arquitectónica española durante la época de los primeros borbones (1700-1770)». Quintana, 2003, 2, pp. 57-94.

53. CRespo. Un viaje..., op. cit. 
arte español, y de manera específica su arquitectura en su segunda mitad, fue una opinión extendida en la literatura dieciochesca, no sólo en la artística. Por un lado, se adecuaba a un lugar común como era el desarrollo y el poder alcanzado por España en ese momento; por otro, a una necesidad de configurar una identidad de prestigio para el país.

Desde la experiencia que le proporcionaban sus peregrinajes por la Península, Ponz escribió que, dada la multitud de edificaciones erigidas en España durante esas décadas, si se hubiera continuado construyendo con tal acierto, "pudiera hoy gloriarse esta nación de ser igual o superior a las que pueden enseñar mayor número de bellos edificios». Aun frustrada esta meta por la irrupción del barroco y los churrigueristas, del siglo XVI se podía decir según Ponz lo que el prestigioso crítico Marc-Antoine Laugier había afirmado del XVII en Francia, "y es haber tenido sus Bramantes, sus Miguel Ángel y sus Vignolas, y que la Naturaleza, en materia de talentos, agotó su fecundidad». La conclusión era sugestiva: «el siglo XVI llegó a producir obras de arquitectura en España dignas de la edad más culta y artífices que merecieron inmortal fama ${ }^{54}$. La arquitectura, por tanto, había gozado en España de una época de modélico esplendor y esto resultaba significativo para las bellas artes, necesitadas de ejemplos para su regeneración, pero también para la nación.

Desde esta perspectiva, parece lógico que una de las principales preocupaciones de esta erudición fuese reafirmar la atribución española de El Escorial, frente a algunos autores extranjeros que lo vinculaban a arquitectos italianos o franceses. Sin ir más lejos, Ponz redirigió su Viaje para hablar cuanto antes sobre El Escorial y así desmentir "varias opiniones radicadas, y que todavía se van propagando acerca de algunos puntos esenciales" sobre el edificio y sus responsables ${ }^{55}$. Eugenio Llaguno afirmó iniciar su recopilación de noticias sobre la arquitectura española para contestar su desconocimiento por parte de los extranjeros, especialmente sobre su monumento y arquitecto emblemáticos ${ }^{56}$. Todavía en 1819, Ceán Bermúdez escribía una contundente carta al arquitecto parisino Louis-Hippolyte Lebas donde reincidió en la plena autoría de Juan Bautista de Toledo y Juan de Herrera, subrayando además que Felipe II había impuesto que el trazador de su palacio fuese español. Ceán no perdió la oportunidad para mostrar no tanto su perplejidad por la pervivencia de errores y prejuicios sobre El Escorial, sino sobre todo para reivindicar el antiguo esplendor del país:

54. PonZ, Antonio. Viage de España. Madrid: Imprenta de Joaquín Ibarra, 1772-1794, t. VII, Prólogo, V-VI. No se equivocaba al afirmar que Laugier había encumbrado a los arquitectos franceses del siglo XVII: Calatrava. Arquitectura..., op. cit., pp. 269-292.

55. CRESPO. Un viaje..., op. cit.

56. CERA BREA, Miriam. "Los inicios de la historiografía arquitectónica en España: las noticias de los arquitectos y la problemática de su doble autoría.. En Teoría y literatura artística en España. I Congreso Internacional ss. XVI-XVIII. Madrid: Real Academia de Bellas Artes de San Fernando, 2015, pp. 311-329. 
¿Tan presto se han olvidado del poder, autoridad, civilización y grandeza de la España en el siglo XVI y del valor, espíritu, ingenio, talento y despejo de los españoles en las armas, en las ciencias y en las bellas artes, y de los vehementes estímulos y causas que tuvieron entonces para conocerlas y ejercitarlas? ${ }^{57}$.

Resulta significativo que el declive predicado de las nobles artes a finales del siglo XVII, y de manera especial de la arquitectura a principios del XVIII, se vinculase a la manida crisis política y cultural de España en ese periodo. Ceán expresó con contundencia la estrecha relación entre las artes y las ciencias en un discurso dedicado, precisamente, a desentrañar el origen de dicha decadencia de la arquitectura y que, por añadidura, leyó en la Academia de la Historia: "Las ciencias y las nobles artes, como buenas compañeras, son inseparables en sus progresos y desgracias ${ }^{58}$. Compartiendo este principio, los eruditos pretendieron precisar los motivos del encumbramiento del barroco. Desde los tratados de Luzán y Mayans se afirmó que un estilo afectado se había impuesto en la literatura española de las últimas décadas del siglo XVII. Llaguno no dudó en relacionar el éxito del churriguerismo con el de las extravagancias gerundianas de oradores y poetas coetáneos. "El buen o mal gusto camina entre las cosas a un mismo paso", proclamó59. Este argumento generó otras teorías que ahondaron en la conexión entre dichos ámbitos. Si Ponz señaló al italiano Luca Giordano como el principal responsable del definitivo derrumbamiento de la pintura en España tras su llegada a la Península en $1692^{60}$, Jovellanos dio un paso más y lo equiparó con Lope de Vega. Para Jovellanos, ambos autores estuvieron dotados de grandes habilidades, pero se preocuparon más por producir mucho que por hacerlo bien. Arrastraron tras de sí «los ojos del vulgo y aun los de muchos profesores», aunque fuese más que por el mérito intrínseco de sus obras, "por su pompa y aparente armonía". Si uno produjo una saga de poetas «insulsos, afectados y charlatanes; el otro... unos pintores atrevidos, incorrectos y amanerados». Su legado era desolador: «Desterraron el orden, la regularidad y la decencia de la poesía y la pintura " ${ }^{61}$. El destino de las letras y de las bellas artes había resultado tristemente parejo.

Pero más allá de esta equiparación entre las bellas artes y la literatura, que conllevaba la consideración de las primeras como rasgo privilegiado de la evolución cultural, nos parece interesante incidir en que Giordano permitió atribuir

57. Ceán Bermúdez, Juan Agustín. "Respuesta de Don Juan Agustín Ceán-Bermúdez a M. H. Le Bas, arquitecto de Paris, sobre ciertas preguntas que le hizo, acerca de lo que Jacobo Barozio Vignola y otros artistas extranjeros habian trazado y construido en la suntuosa fábrica del real Monasterio de $S$. Lorenzo del Escorial. Escrita en Madrid el año de 1819". En Ocios de Don Juan Agustín Ceán-Bermúdez sobre Bellas Artes. Madrid: Imp. de Berenguillo, 1870.

58. CeÁn Bermúdez, Juan Agustín. El churriguerismo. Discurso inédito por D. -. Santander: Boletín de la Biblioteca Menéndez Pelayo, 1921, p. 8.

59. Llaguno. Noticias..., op. cit., t. IV, p. 107.

60. Crespo. Un viaje..., op. cit.

61. Jovellanos. Elogio de las bellas..., op. cit. 
la decadencia a un artista extranjero. De hecho, la figura del italiano se llegó a contraponer a la de su contemporáneo español Claudio Coello, calificado como la última esperanza de la pintura nacional y que fallecería por la tristeza que le causaron los privilegios y honores concedidos por el rey a Giordano, su competidor. En un texto prácticamente inédito pero de gran interés titulado Descripción de la Pintura de la Santa Forma en el monasterio del Escorial, dedicado a la celebérrima obra de Coello, Ceán subrayó que si desde Italia habían llegado grandes maestros a España, con Giordano arribó su destructor y quien apagó su último resplandor ${ }^{62}$.

En la arquitectura se produjo un movimiento similar. Tomando como referencia la tratadística francesa e italiana, Borromini acabó perfilándose entre los eruditos españoles como el primer gran corruptor de la arquitectura. Se afirmó que la estancia en la Roma barroca de Francisco Herrera el Mozo y de José Jiménez Donoso les habría permitido conocer de primera mano las corrientes borrominescas, exportándolas a España a su vuelta ${ }^{63}$. Pero hubo a quien esto no le pareció suficiente. En su Origen del churriguerismo (1816), Ceán describió con prolijidad una obra que había descubierto recientemente, la Architectura de Wendel Dietterlin, en concreto, su edición de Núremberg de 1598, repleta de fantasiosos grabados manieristas. Los calificó de parto de una imaginación delirante y aseguró que tales grabados habían sido la fuente de inspiración de todo el repertorio de la "secta churrigueresca». Tras su lectura en la Academia de la Historia, se aplaudió este trabajo «en que se liberta a nuestra nación del borrón de haber producido los abortos y extravíos del Churriguerismo" ${ }^{64}$. No era poco.

La presunta restauración de las nobles artes a lo largo del siglo XVIII bajo la égida de la nueva dinastía en el poder, los Borbones, se presentó como un nuevo ejemplo de que éstas evolucionaban a la par de la sociedad. El tan cacareado renacimiento del país cantado por todos los panegiristas borbónicos también se dijo constatarse en las artes. Del mismo modo que las letras, las ciencias y el propio Estado habían recuperado su vigor, las bellas artes mostraban la esperanzadora época abierta tras la Guerra de la Sucesión. Jovellanos llegó a escribir que Felipe V, antes incluso de cruzar los Pirineos, tenía ya la intención de regenerarlas ${ }^{65}$. No se hizo sin problemas y resistencias, pero se declaró que

62. Ceán Bermúdez, Juan Agustín. Descripción de la Pintura de la Santa Forma en el monasterio del Escorial. Biblioteca Nacional de España, Ms. 21454-6, f. Gr.

63. Jovellanos. Elogio de Ventura..., op. cit.

64. CEÁn. El churriguerismo..., op. cit., p. 18. Sobre esta posible vinculación: GALERA ANDREU, Pedro. "Naturalismo y antinaturalismo en el ornato barroco hispano: la discutida huella de Dietterlin en España». En Actas del X Congreso del CEHA. Madrid: UNED, 1994, pp. 493-500; Blasco EsQuivias, B. "Wendel Dietterlin y el origen del Barroco en España. Notas sueltas". En PiAzZA, S. (dir.). Testo, immagine, luogo. La circolazione dei modelli a stampa nell'architettura di età moderna. Palermo: Caracol, 2013, pp. 99-109.

65. Jovellanos. Elogio de las bellas..., op. cit. 
la constancia de unos reyes singularizados con los mejores trazos consiguió reconducir la situación. De hecho, las bellas artes fueron uno de los recursos propagandísticos utilizados por los Borbones y sus cortesanos para exhibirlos como los restauradores de los esplendores perdidos en la historia reciente. Iglesias, palacios y retablos, pero también canales, caminos y arsenales se perfilaron como testimonio del nuevo pulso que vivificaba al país. Mientras que extranjeros o exiliados -ya a principios del XIX- pusieron en duda la excesiva grandeza de algunas infraestructuras territoriales iniciadas por los Borbones, desde la propia España se repitió que estaban abriendo luminosos horizontes ${ }^{66}$. El principal héroe del Viaje de España de Ponz fue Carlos III; su reforma de Madrid, superando lo que otrora parecían obstáculos insalvables, se convirtió en símbolo de los nuevos tiempos por los que clamaron los más cercanos a la Corte ${ }^{67}$. La literatura artística contribuyó a forjar algunos de los mitos que exaltaron la labor de los primeros reyes borbónicos. En una obra de la relevancia del Ensayo de una biblioteca española de los mejores escritores del reynado de Carlos III (1785-1789), dedicada a desgranar los méritos literarios de los autores españoles de dicho periodo, Sempere y Guarinos afirmó que las bellas artes eran las disciplinas que más avances habían logrado bajo el caracterizado como ilustrado gobierno de Carlos III ${ }^{68}$. Algo que, por cierto, ya apuntó en su Discurso sobre el gusto actual de los españoles en la literatura incluido en su traducción de las Reflexiones sobre el buen gusto en las ciencias y en las artes (1782) de Luis Antonio Muratori69. En esta obra incluso dio un paso más al afirmar que las nobles artes, con su vuelta a la "belleza, la proporción y el decoro», habían contribuido a la recuperación de otros ámbitos al difundir los principios sobre los que residía el «buen gusto». No cabía considerarlas, por tanto, sólo una mera visualización de los cambios de una sociedad, sino un elemento activo de los mismos.

\section{2. «... HEMOS TENIDO NUESTROS SIGLOS DE PREPONDERANCIA EN LA EUROPA»}

El pasado de las bellas artes se trazó siguiendo los esquemas propios de las Luces. Los cambios señalados en la historia civil o cultural tuvieron su correlato en la de las artes. Difícilmente hubiese podido ser de otro modo, pues la Historia de

66. Crespo Delgado, Daniel. "Conquistar los ríos. Literatura e iconografía de las obras hidráulicas en la España de la Ilustración». En Obras Hidráulicas de la Ilustración. Madrid: CEDEX, Fundación Juanelo Turriano, 2014, pp. 27-39.

67. Abordamos estas cuestiones en Crespo Delgado, Daniel. Árboles para una capital. Árboles en el Madrid de la Ilustración. Madrid: Doce Calles, Fundación Juanelo Turriano, 2012.

68. SEMPERE y GuARINOS, Juan. Ensayo de una biblioteca española de los mejores escritores del reynado de Carlos III. Madrid: Imprenta Real, 1785-1789, t. V, pp. 1-2.

69. SEMPERE Y GUARINOS, Juan. "Discurso sobre el gusto actual de los españoles en la literatura". En MURATORI, Luis Antonio. Reflexiones sobre el buen gusto en las ciencias y en las artes. Madrid: Antonio de Sancha, 1782, p. 277. 
la Ilustración hizo suya la de las nobles artes, construyéndose desde sus principios y constituyéndose en una de sus partes. Si sus mudanzas corrieron en paralelo -una prefiguración de aquella falacia criticada por Gombrich de entender todos los estratos de la Historia como los radios de una rueda avanzando en la misma dirección $-{ }^{70}$ los objetivos de sus relatos también se encontraron.

Como acabamos de ver, una de las ideas recurrentes fue la reivindicación de la riqueza artística del país. Se insistió no sólo en la cantidad de obras y artistas de prestigio que podían localizarse en el solar propio, sino en los fulgores que las bellas artes habían alcanzado en todos los periodos, hasta en las épocas en las que Europa se encontraba inmersa en una profunda crisis. A veces sus destellos habían sido inigualables o resplandecieron tanto como los centros más prestigiosos; en otras fueron las únicas luces de un mundo en retirada. Se insistió en que su legado monumental mostraba una España que siempre había mantenido un gran vigor, que había participado y contribuido de manera decisiva a los adelantos producidos en el continente; algo que en un momento de extendido eurocentrismo era tanto como decir a la civilización. Fue una lástima que las sugestivas aportaciones hechas en estas décadas del arte precolombino e incluso del colonial no traspasasen la reflexión sobre América, al menos en nuestro caso, no llegándose a integrar en los discursos referidos al arte español ${ }^{71}$. Exceptuando algún nombre muy concreto, a los eruditos centrados en su estudio sólo les preocupó situar al país en el contexto europeo. En todo caso, no deja de ser significativa la defensa del papel de los artistas nacionales en los periodos más sobresalientes: se subrayó que las apreciadas obras de la Hispania romana se debían a maestros foráneos pero también a indígenas; se argumentó sin desmayo que El Escorial se debía a arquitectos españoles. Con el mismo sentido, pero en una dirección inversa, se llegó a atribuir a extranjeros o a influjos procedentes de allende los Pirineos las corrientes que habían conducido a las bellas artes a su presunta ruina.

Las palabras impresas se juzgaron insuficientes para difundir tal riqueza patrimonial, sobre todo al afirmarse que su desconocimiento había provocado su injusta infravaloración. Como en otros ámbitos, se confió en una orquestada tarea de difusión, que en este caso tenía posibilidades particulares. En 1786, Diego Rejón de Silva incidió en que la falta de desarrollo del grabado español había contribuido a que nuestros maestros fuesen generalmente ignorados. Propuso estampar obras de algunos de los autores más relevantes ${ }^{72}$. Un año después y por las mismas razones, Bosarte defendió la confección de un ambicioso «museo

70. Gombrich, Ernst H. Ideales e ídolos: ensayos sobre los valores en la bistoria y el arte. Barcelona: Gustavo Gili, 1981.

71. CRespo Delgado, Daniel. "El gran mapa de la humanidad y las bellas artes prehispánicas durante la Ilustración». Anuario de Estudios Americanos, 2008, 65, 2, pp. 125-150.

72. Rejón DE SIlva, Diego. La Pintura. Poema didáctico en tres cantos. Segovia: Antonio Espinosa de los Monteros, 1786, p. 104. Véase PeÑa Velasco, Concepción de la. «Rejón de Silva y el discurso ilustrado sobre la escuela española». Atrio, 2013, 19, pp. 69-83. 
arquitectónico español» y de una "galería española de estampas»" Desde Italia, Juan Andrés reafirmó el interés que despertaría entre los extranjeros grabar las producciones de los más insignes pintores españoles. De hecho, este autor escribió una carta a Bosarte donde confirmaba que "nuestras bellas artes son muy poco conocidas" y que esto "no dejaba de ser en desdoro de nuestra patria»" Años después, el sucesor de Bosarte en la secretaría de la Academia de San Fernando, José Luis Munárriz, desempolvaba dichos proyectos advirtiendo de las muchas obras de primera categoría artística en la nación, "porque hemos tenido nuestros siglos de preponderancia en la Europa ${ }^{75}$.

No todo se quedó en meras declaraciones, puesto que a lo largo del periodo se sucedieron iniciativas, con desigual fortuna, para grabar el patrimonio artístico español o algunas de sus principales obras ${ }^{76}$. Lo que no variaron fueron los argumentos. Incluso cuando en 1819 se anunció la apertura del Real Museo de Pinturas en el Paseo del Prado de Madrid, se anotó que la voluntad del monarca era "franquear al público una copiosa colección de cuadros nacionales y extranjeros por el orden de las diferentes escuelas». Si bien se iba trabajando en la exposición de pinturas de la escuela italiana, flamenca, holandesa, alemana y francesa, de momento sólo se abrirían las salas dedicadas a la española, "que tanto se distingue aun entre las de otras naciones que han cultivado con gloria las nobles artes ${ }^{77}$. La Colección Lithographica de cuadros del Rey de España, iniciada en 1826, otorgó una importancia especial a los pintores españoles colgados en el Prado, ya vindicados en el prólogo firmado por José Madrazo y donde también se hizo referencia al dolor que el "orgullo nacional» sentía por el olvido de sus glorias.

Esta reivindicación del arte y de los artistas españoles contribuía a la del propio país, afianzaba su maltrecho prestigio frente a quienes lo ponían en duda, y reforzaba el sentimiento de pertenencia a una comunidad definida cada vez

73. Bosarte. Discurso..., op. cit., papel II, pp. 41 y ss.

74. ANDrÉs. Carta..., op. cit., t. I, p. 208; Diario de Madrid, 26 de marzo de 1788.

75. Lo publicó en un artículo aparecido en el Semanario de Salamanca, de 21 de enero de 1794. Este artículo fue el primero de una serie que vieron la luz en este mismo periódico el 19 de abril, el 3 de junio y el 2 de setiembre de 1794, el 11 de abril y el 26 de setiembre de 1795, y el 15 de marzo de 1796. Apuntemos que en 1796 Munárriz presentó estos textos en forma manuscrita a la Academia de San Fernando (Archivo de la Real Academia de Bellas Artes de San Fernando, Sign. 327/3). Los números del Semanario que posee la Hemeroteca Municipal de Madrid suponemos que pertenecieron al mismo Munárriz (que firmó con diversos seudónimos, en especial con el de Pablo Zamalloa), ya que sólo sus artículos aparecen con rectificaciones y notas manuscritas.

76. Estampas de la Calcografía Nacional. La Colección Real de Pintura 1791/1798. Madrid: Comunidad Autónoma, 1984; PORTús, Javier y VEGA, Jesusa. La estampa religiosa en la España del Antiguo Régimen. Madrid: FUE, 1998; Crespo. Un viaje..., op. cit.; El legado..., op. cit.

77. Gaceta de Madrid, 18 de noviembre de 1819. Para el papel jugado por el Prado desde su creación en el conocimiento y la difusión de la escuela española MATILLA, José Manuel y PorTús, Javier: "Ni una pulgada sin cubrir. La ordenación de las colecciones en el Museo del Prado, 1819-1920". En El grafoscopio. Un siglo de miradas al Museo del Prado (1819-1920). Madrid: Museo Nacional del Prado, 2004, pp. 15-125. 
más como nación. Esta lectura fue posibilitada por la consolidación de lo artístico como signo de ilustración y la revisión del concepto mismo de civilización y progreso. Además, acabamos de ver que el patrimonio artístico podía difundirse con una amplitud y unos recursos sugestivos y característicos.

Ponz afirmó que los monumentos eran "el sobrescrito de una nación", infiriéndose "el estado de cultura que hay en ella" de su regularidad, deformidad o grandeza $^{78}$. De ahí que en otro lugar de su influyente Viaje escribiese que "las obras públicas ejecutadas con arte forman el primer capítulo de las alabanzas de un pueblo». Citó seguidamente una serie de emblemáticos edificios españoles que manifestaban la ilustración del país a lo largo de la Historia. El Escorial, no cabe decirlo, le mereció una mención especial:

Últimamente, es tan natural honrarse una nación con los célebres edificios de ella, que si un español, hallándose fuera del reino, ve combatir su patria en esta línea, desde luego se arma, y con mucha razón, con la magnífica obra de El Escorial ${ }^{79}$.

No se equivocaba Ponz al atribuir al patrimonio artístico una significación que traspasaba lo meramente disciplinar. Por ello, los trabajos que lo daban a conocer se presentaron como una contribución al país, llegando a adoptar una retórica patriótica. Por otro lado, las bellas artes participaron del polémico debate contemporáneo sobre la aportación de España a la civilización. Y no sólo lo hicieron desde la literatura artística.

En las obras surgidas al calor del famoso artículo sobre España de Masson de Morvilliers, las bellas artes, aunque tuviesen un papel secundario, no se ignoraron. En sus Observaciones sobre el artículo España de la Nueva Encyclopedia (1784), Antonio Cavanilles ofreció una detallada relación de personalidades históricas y contemporáneas que mostraban el elevado nivel cultural del país ahora y en el pasado. En ese marco, afirmó la autoría española de El Escorial ${ }^{80}$, se refirió a modélicos artistas de los siglos XVI y XVII y a un nutrido grupo de maestros contemporáneos que, en las últimas décadas, bajo el amparo de la nueva dinastía, habían resucitado las bellas artes ${ }^{81}$.

78. PONZ. Viage..., op. cit., t. XI, I, pp. 16 y 17.

79. Ibídem, t. VII, Prólogo, IV.

80. Según Cavanilles, tras la restauración de las artes en Italia, mientras Francia contaba con arquitectos mediocres, España ya tenía sus «Diego de Silva [Siloé], Berruguete, Cobarruvias» (CAVANILLES Antonio José. Observaciones sobre el artículo España de la Nueva Encyclopedia. Escritas en frances por el doctor-y traducidas al castellano por D. Mariano Rivera. Madrid: Imprenta Real, 1784, p. 21). También hizo referencia a lo afirmado por Voltaire respecto a El Escorial, señalando que fue Jacques Auguste de Thou quien le llevó a equivocarse y atribuirlo a un maestro foráneo. Sobre esta errónea atribución de Voltaire, ver IGLESIAS, M. ${ }^{a}$ del Carmen. "Una imagen oriental en la España en el siglo XVIII". En Homenaje académico a D. Emilio García Gómez. Madrid: Real Academia de la Historia, 1993, p. 412.

81. En palabras de Cavanilles, la España medieval fue «el centro, donde se reunía entonces todo lo que restaba en Europa de conocimientos e instrucción» (CAVANILlEs. Observaciones..., op. cit., p. 94). Mas fue en el siglo XVI cuando el país vivió su particular siglo de oro también manifiesto en las bellas 
Las alusiones a las nobles artes en la Oración Apologética por la España y su mérito literario (1786) de Juan Pablo Forner fueron más puntuales pero igual de reveladoras. Sólo citó un puñado de artistas del pasado - a Ribera, Murillo, Velázquez y Juan de Herrera-, si bien vinculó las altas cimas que alcanzaron al verdadero «espíritu filosófico» que dominó los antiguos tiempos y que él abogaba por mantener ${ }^{82}$. También Carlo Denina en su Réponse á la question que doit-on à l'Espagne? (1786) se centró en artistas del pasado, en concreto del siglo XVI, mencionando a Berruguete, Becerra, Navarrete, Vargas y Pérez de Alesio ${ }^{83}$. Tan particular nómina de artistas se explicaría por la pretensión del autor por relativizar el papel cultural de Francia. Según Denina, tales artistas renacentistas revelaban que las artes florecieron en España antes que en Francia, deduciendo de ello que el impulso adquirido durante el siglo XVII bajo el reinado de Luis XIV se remitía a Francisco I, cuyo interés por estas disciplinas se despertó durante su encarcelamiento en Madrid, viéndolas tan adelantadas en el país enemigo y tan poco en el propio. En opinión de Denina, por tanto, en la base de los fastos artísticos franceses del siglo XVII, como en otros aspectos culturales y literarios, se encontraba la huella española.

artes: «QQué le falta al Escorial para ser uno de los primeros edificios del Universo?... ¡Qué multitud de grandes Pintores florecieron entonces!...» (CAVANILles. Observaciones..., op. cit., p. 107). Cavanilles se sumó a quienes dijeron que el siglo XVII fue una época de crisis para España, hasta el punto de que «a estos infelices tiempos se podría aplicar con razón la sátira de Mr. Masson: al fin de este siglo XVII fue cuando las ciencias y artes fueron enteramente abandonadas». De todos modos, el apologista señaló excepciones en tan negro panorama. Por ejemplo, en las bellas artes con Velázquez, Palomino y algún que otro discípulo de Gregorio Fernández (CAVAnilles. Observaciones..., op. cit., pp. 110-111). La llegada de los Borbones había supuesto la superación de dicho estado de postración, siendo, por tanto, improcedentes las acusaciones de Masson tanto sobre el pasado como sobre el presente de España.

82. FORNER, Juan Pablo. Oracion Apologética por la España y su mérito literario: para que sirva de exornacion al discurso leido por el Abate Denina en la Academia de Ciencias de Berlin, respondiendo a la qüestion qué se debe á España? Madrid: Imprenta Real, 1786, p. 149. Forner citó a este ya tópico puñado de artistas tras alabar las consecuciones filosóficas de los españoles durante el siglo XVI y especialmente de Juan Luis Vives, convertido por el extremeño en el padre de los saberes modernos, anticipándose al propio Francis Bacon. Pues bien, después de deshacerse en elogios a Vives, Forner escribió: “¿Y no osaré yo afirmar que el verdadero espíritu filosófico, más racional y menos insolente que el ponderado de nuestros días, comunicado a todas las profesiones y artes en aquel meditador siglo, perfeccionó también las que sirven a la ostentación del poder humano; que copian los vivos seres de la Naturaleza; que levantan soberbios testimonios de la inventora necesidad del hombre? ¿pudo ser Herrera el Arquitecto del Escorial sin filosofía? Sin ella Ribera, Murillo, Velázquez con breve pincel, los émulos del poder divino?» (ForNer. Oracion..., op. cit., p. 149). Sobre la comparativamente escasa presencia de artistas en la Oración Apologética, ver CAÑas, Jesús. "Autoridad y autoridades en la Oración Apologética de Forner». En CAÑAs, Jesús y Lama, Miguel Ángel (coords.). Juan Pablo Forner y su época. Mérida: Editora Regional de Extremadura, 1998, pp. 303-377.

83. Denina, Abbé. Réponse á la question que doit-on à l'Espagne? Discours lu à l'Académie de Berlin dans l'Assemblée Publique du 26 janvier l'an 1786 pour le jour anniversarire du Roi. Madrid: Imprenta Real, 1786, p. 37. 
Fuese en la prensa periódica (véase por ejemplo un artículo aparecido en el Correo de Murcia del 17, 21 y 24 de junio de 1794) o en obras como la Tabla o breve relación apologética del mérito de los españoles en las Ciencias, las Artes, y todos los demas objetos dignos de una nación sabia y culta (1786) de Santos Díez González, monumentos y artistas no se olvidaron cuando se abordó la "cuestión de España». El propio Díez González adelantó el motivo en su título: las nobles artes abundaban en «las naciones sabias». No por otra razón pretendió demostrar que España "fue la primera, que entre todas las Naciones, excepto la Italiana, tuvo excelentes Profesores de las bellas Artes, Pintura, Escultura y Arquitectura "84.

Algo similar quiso probar en sus Cartas sobre la Italia (1787) el jesuita José García de la Huerta. En esta diatriba en la que se intentó relativizar las aportaciones italianas frente a las hispanas, incluso las bellas artes se utilizaron como un argumento que equiparaba ambos lugares ${ }^{85}$. Lo cierto es que José García de la Huerta no fue el único jesuita expulso español que recurrió a dichas disciplinas para defender el mérito y la debida consideración de su país de origen. Entre la amplia tarea apologética llevada a cabo por los jesuitas emigrados a Italia, en nuestro ámbito cabría destacar las Observaciones de Don Ramón Diosdado Caballero, sobre la patria del pintor Josef de Ribera llamado el Españoleto, documentando el nacimiento de Ribera en España frente algunas fuentes italianas que lo hacían napolitano ${ }^{86}$, o la adaptación del Viaje de España de Ponz publicada por Antonio Conca en Parma como Descrizione odeporica della Spagna in cui spezialmente si dà notizia delle cose spettanti alle belle arti degne dell'attenzione (1793-1797). Su título ya desvela que Conca prescindió de los problemas económicos y sociales abordados por Ponz en su Viaje. Incluso no prestó demasiada atención a sus censuras al barroco tardío, centrándose en dar noticia casi de manera exclusiva de los monumentos de interés que se encontraban en España, como si huyese de cualquier mota que pudiese empañar sus bondades y bellezas. Sus objetivos fueron diáfanos: "far osservare il successivo, e vario stato delle belle Arti in Spagna dopo il loro ristabilimento nell'Europa». Con ello demostraría a sus lectores que en la península vecina se podían encontrar importantes cuadros de autores europeos y nacionales. Es más, reafirmó una de las principales tesis de nuestra erudición, la existencia de una «nuova Scuola delle belle Arti, che merita di essere distinta col titolo di Scuola Spagnuola ${ }^{87}$.

84. DíEz GonzÁlez, Santos. Tabla o breve relación apologética del mérito de los españoles en las Ciencias, las Artes, y todos los demas objetos dignos de una nación sabia y culta. Madrid: Blas Román, 1786, pp. $85-88$.

85. Biblioteca Nacional de España, Mss. 6482, t. II, f. 22v.

86. Diosdado Caballero centró su actividad intelectual, como tantos otros jesuitas expulsos, en el estudio y la defensa de la cultura española (SORIANO MuÑOz, Nuria. "Inventando el pasado, creando la nación: la aportación de Diosdado Caballero». Cuadernos Dieciochistas, 2013, 14, pp. 137-160). Las Observaciones fueron publicadas en Italia en 1795 y en 1828 se tradujeron al español.

87. Conca, Antonio. Descrizione Odeporica della Spagna in cui spezialmente si da notizia alle Belle Arti degne dell'attenzione del curioso viaggatore. Parma: Stamperia Reale, 1793-1797, t. I, pp. I y VII. 
Entre las fuentes jesuitas, merece destacarse de igual modo el Ensayo histórico-apologético de la literatura Española contra las opiniones preocupadas de algunos Escritores modernos Italianos (1782-1786) de Francisco Javier Lampillas. En el tomo IV (1784) abundó en el lugar común del gran desarrollo alcanzado por la literatura española en el siglo XVI; lo particular es que insertase un capítulo dedicado a las nobles artes ${ }^{88}$. Según Lampillas, en un siglo tan glorioso para España no pudieron faltar los fulgores de tales disciplinas, considerándolas, una vez más, "compañeras inseparables de la docta literatura; de modo, que a un mismo tiempo renacen y mueren las bellas artes y las bellas letras ${ }^{89}$. Basándose en el Parnaso de Palomino y el Viaje de Ponz, elogió al gran número de maestros españoles del siglo XVI que se sumaron al Renacimiento, brillando con especial intensidad Juan de Herrera, Juan Bautista de Toledo y Juan Bautista Monegro. A los dos primeros se les debía la traza de El Escorial, definido por Lampillas como «un monumento eterno no menos a la religión española, que a la pericia de los españoles en las bellas artes $»^{90}$.

Se revela que si, en la definición del estado de una comunidad, las bellas artes podían ser significativas, no se juzgaron menos en el relato de su pasado; al consolidarse como expresivo indicador cultural, dichas disciplinas se situaban en el corazón de la propia Historia, pudiendo esclarecer algunos de sus capítulos. Esta relación, en la que diversos autores del periodo incidieron, ya no iba a romperse. En su Historia de la civilización española (1840), Eugenio de Tapia censuró a los "fríos calculistas" que despreciaban la importancia de las nobles artes. Afirmó que éstas seguían "siempre los progresos de la civilización", dedicando varias páginas a su evolución partiendo, fundamentalmente, de las aportaciones de Jovellanos y Ceán ${ }^{91}$. Medio siglo antes, en 1790, habían tenido lugar los primeros ejercicios

88. El Saggio storico-apologetico della Letteratura Spagnuola de Lampillas se publicó en Italia entre 1778 y 1781. Poco después, entre 1782 y 1786, apareció una traducción al español a cargo de Josefa Amar Borbón. SANHUESA FONSECA, María. «La obra de Javier Lampillas (1731-1810) y la defensa de la literatura y música españolas». En El Mundo Hispánico en el Siglo de las Luces. Madrid: Editorial Complutense, 1996, t. II, pp. 1193-1204.

89. LAMPILlas, Francisco Javier. Ensayo bistórico-apologético de la literatura Española contra las opiniones preocupadas de algunos Escritores modernos Italianos. Traducido del italiano al español por Doña Josefa Amar y Borbon. Zaragoza: Blas Miedes, 1782-1786, t. IV, p. 339.

90. LAmpillas. Ensayo..., op. cit., t. IV, p. 349. Para demostrar la autoría española de El Escorial, Lampillas se remitió a la inscripción que rezaba en su entrada y a la medalla de Herrera, subrayando que "estos y otros convencimientos pueden verse en el insigne Don Antonio Ponz" (LAMPILLAS. Ensayo..., op. cit., t. IV, p. 350). No casualmente, en la carta que Ceán Bermúdez escribió a Ponz en noviembre de 1779 dándole a conocer la estampa sobre Herrera de Otto Venius y grabada por Perret, le confesó que «me alegraría que el abate Lampillas hubiera tenido noticia de esta estampa cuando hizo el elogio del autor de la obra del Escorial» (Biblioteca Nacional de España, Mss. 21454-3).

91. TAPIA, Eugenio. Historia de la civilización española, desde la invasión de los árabes hasta la época presente. Madrid: Imprenta de Yenes, 1840, t. III, pp. 188-201. La deuda de la obra de Tapia con la Historia de la Civilización Europea (1828) de François Guizot es clara. BERNALDO DE QuiRós MAteO, José Antonio. El escritor Eugenio de Tapia, un liberal del siglo XIX. Ávila: Caja de Ávila, 2003. 
públicos del curso inaugural de la Cátedra de Historia Literaria de los Reales Estudios de Madrid. Se centraron en la historia antigua y, entre varias conferencias que abordaban temas literarios, filosóficos o religiosos, se incluyó una dedicada a las «bellas Artes entre los antiguos hasta la conquista de Grecia por los romanos» a cargo de Bosarte. Esta lección se publicó en $1791^{92}$. El principal impulsor de estos estudios y de sus ejercicios públicos, Miguel de Manuel, escribió que el fin de la cátedra eran "todos los conocimientos humanos, presentados en sus orígenes, en sus edades y en sus diversos estados" "3.

Aunque sostenida por los principios de las Luces, la riqueza artística de España potenció esta lectura in extenso puesto que desde sus monumentos podía mostrarse un pasado esplendoroso y hasta convencer de un futuro esperanzador. Adaptar el legado artístico propio a las categorías estéticas ilustradas no fue un problema insoluble. El influyente pintor y teórico neoclásico Anton Raphael Mengs mostró su distancia y sus dudas respecto al arte español ${ }^{94}$. No obstante, rápidamente fue contestado y desde Ponz a Ceán se pudo trazar una prestigiosa narración del arte nacional que encajase con los hegemónicos principios clásicos. Tal fue la razón de la exaltación de Herrera y de su tiempo. Del mismo modo, ciertos periodos reputados -el caso más significativo es el de la pintura barroca o, al menos, el de algunos de sus principales maestros- se releyeron para integrarse en tal relato ${ }^{95}$. De hecho, la Historia, cuya curiosidad y anhelo de totalidad motivó el adentrarse en distintas épocas, acabó ayudando a reconocer las particularidades de cada una de ellas, hizo del tiempo un valor cada vez más asentado, erosionando las posturas más ortodoxas del clasicismo y transformando el gusto.

Se afirmó contar, por tanto, con un amplio patrimonio artístico que respondía a los principios intelectuales y estéticos que el pensamiento contemporáneo había consagrado como referentes. Esto lo convirtió en un argumento privilegiado no sólo para fortalecer el prestigio del país, sino también para la reformulación de la identidad propia pretendida por la Ilustración. Brillantes episodios artísticos, como fue el caso de los literarios o científicos, alejaban a España de una insidiosa caracterización de país atrasado y oscurantista, otorgándole un lugar entre las Luces, aun en su definición más temperada. Conformar una tradición ilustrada

92. Simón DíAz, José. Historia del Colegio Imperial de Madrid. Madrid: Instituto de Estudios Madrileños, 1992; ROMERO REcio, Mirella. "La historia antigua en la enseñanza: los ejercicios públicos de historia literaria en los Reales Estudios de San Isidro (1790-1791)». Cuadernos del Instituto Antonio de Nebrija, 2004, 7, pp. 235-262.

93. Exercicios publicos de bistoria literaria: que tendrán en los Estudios Reales de Madrid los señores... asistidos del catedrático de historia literaria D. Miguel de Manuel... Madrid: Benito Cano, 1790 , p. 1.

94. Mengs, Antonio Rafael. Obras de D. Antonio Rafael Mengs, primer pintor de Camara del rey, publicadas por Don Joseph Nicolas de Azara. Madrid: Imprenta Real, 1780. ÚBEDA. Pensamiento..., op. cit.

95. ÚBEDA DE los CoBOS, Andrés. “¿Zeuxis o Velázquez? La reivindicación nacionalista en la definición del primer neoclasicismo español». Hispania: Revista Española de Historia, 1996, 192, pp. 51-62. 
posibilitaba que los caminos indicados para el desarrollo no se viesen como algo totalmente nuevo, una ruptura radical con el pasado, ni que tampoco se tuviesen que buscar fuera de manera necesaria. Éstos eran aspectos nada triviales en un momento en que lo nuevo y lo foráneo, fuera de los sectores más avanzados, continuaban siendo problemáticos. En todo caso, las bellas artes hicieron mirar con mayor esperanza al país al mostrar su capacidad para el progreso, reforzando la confianza en sus posibilidades. Tal y como se describió su estado actual bajo los Borbones, pero no menos su brillante pasado, permitían proclamar un optimismo más o menos forzado. La Historia, en el fondo, era un argumento para el futuro. Es más, al determinarse las causas del desarrollo artístico desde valores moderados, su exposición no supuso ninguna tensión para la Ilustración española, más conservadora que radical en términos generales.

\section{3. "SieMPRE La ESPAÑa FUE MONARQUía..."}

La confluencia de las bellas artes en la Historia implicaba que las causas de su desarrollo y su declive adquiriesen fuertes connotaciones ideológicas. Explicar su evolución desde unos valores u otros no era una decisión intrascendente o restringida a lo erudito o a lo estético. Se fue consciente de ello, como se fue en todo momento del profundo sentido político del relato histórico. Ya advertimos que Juan Pablo Forner, desde una postura conservadora, sólo aludió a prestigiosos artistas del pasado para defender máximas tradicionales que consideraba amenazadas por los «espíritus fuertes». Una idea tan extendida como la consideración del XVI como Siglo de Oro suponía en general la asunción de que bajo un sistema asimilable al existente, al menos en los fundamentos vertebradores de su organización política y social, se podían alcanzar luminosas cimas. Es decir, el sistema quedaba sancionado, reafirmaba su capacidad y potencial, sobre todo por cómo se definió el desarrollo predicado de las bellas artes en el siglo XVI. Y no sólo el de este momento: el adelanto y la decadencia de lo artístico se estableció a partir de principios emparentados directamente con la mentalidad ilustrada y, de manera más específica, como ya apuntamos, con la moderada.

Ninguno de nuestros autores llegó a definir desde el relato histórico un preciso y completo sistema que determinase las condiciones por las que las bellas artes se desarrollaban o decaían. Sin embargo, en sus obras de nuevo damos con una serie de argumentos reiterados y comunes. Se subrayó la importancia de las condiciones ambientales, incidiendo de manera especial en lo decisivo que era la protección efectiva a los artistas y sus producciones. El modélico arte griego, por ejemplo, se remitió en último término al sabio y generoso mecenazgo de sus élites. Campomanes, en un texto tan significativo como el Apendice a la Educacion Popular (1776), se refirió a las razones por las que los griegos se aventajaron en las tres nobles artes. Partiendo de la Historia del Arte de la Antigüedad (1764) de Winckelmann, señaló no sólo la belleza de la naturaleza en Grecia y el 
conocimiento que los artistas tuvieron de los materiales, sino sobre todo a «dos medios de promover las artes, que a mi ver serán siempre los principales para perfeccionarlas y conservarlas florecientes en todo país». Por un lado, el establecimiento de escuelas de dibujo y la inexistencia de gremios; por otro, "la nobleza y los ayuntamientos se aficionaron a las artes a porfía: encargaban muchas obras públicas y suntuosas, pagando con larga mano a los artífices ${ }^{96}$. Precisamente, la fundación de escuelas de dibujo, la limitación de los gremios y, en especial, promover la estimación de los artífices y sus producciones fueron algunas de las medidas que defendió para resucitar no sólo las bellas artes, sino también la decaída industria española.

Campomanes incidió en las benéficas consecuencias que tendría que la nobleza aprendiese dibujo y así se implicase de manera efectiva en el desarrollo de las artes, pudiendo discernir las buenas de las malas obras. Como en sus propuestas económicas y sociales, como en las habituales de nuestra Ilustración, las élites ni quedaban marginadas ni se ponía en duda su poder y sus prerrogativas ${ }^{97}$. Todo lo contrario: lo que se defendía era su adecuada orientación, que llenasen de contenido sus privilegios. Había que contar con élites ilustradas, que cumpliesen con su debido papel y, por encima de todo, como culminación de la estricta jerarquía del Antiguo Régimen, con monarcas providentes. El papel predicado de los reyes, espejo y guía de una sociedad organizada en torno a su figura, también fue incuestionable. En no pocas ocasiones, sus reinados marcaron los periodos en los que se dividió la historia de las bellas artes ${ }^{98}$. Y no sólo por aportar un armazón cronológico: su influjo se juzgó clave. Sin ir más lejos, la historia arquitectónica española trazada desde las Luces pivotó entre dos grandes monumentos palaciegos, El Escorial y el Palacio Real de Madrid. Si El Escorial se afirmó que había significado la definitiva instalación de la ejemplar arquitectura, el Palacio Real, aun con sus reconocidos defectos desde una óptica neoclásica ${ }^{99}$, había logrado devolver la arquitectura a la senda correcta tras el desvarío churrigueresco. Hacia finales del siglo XVIII, el Museo del Prado ya se había consagrado como el edificio emblemático de los últimos tiempos marcados por la plenitud de la restauración borbónica ${ }^{100}$.

96. Rodríguez Campomanes, Pedro. Apéndice a la Educación Popular. Madrid: Antonio de Sancha, 1775-1777, t. III, p. VI.

97. Para el pensamiento económico y político de Campomanes: LlombarT Rosa, Vicent. Campomanes, economista y político de Carlos III. Madrid: Alianza, 1992; Castro, Concepción de. Campomanes. Estado y reformismo ilustrado. Madrid: Alianza, 1997; LLOMBART Rosa, Vicent. "Campomanes, el economista de Carlos III». En FuenTES QuinTANA, Enrique (dir.). Economía y economistas españoles. 3. La Ilustración. Barcelona: Gutenberg, 2000, pp. 201-257.

98. CRespo y García. Ceán..., op. cit.

99. Rodríguez Ruiz, Delfín. "Del Palacio del Rey al orden españo»l. En El Real Sitio de Aranjuez y el arte cortesano del siglo XVIII. Madrid: Comunidad de Madrid, Patrimonio Nacional, 1987, pp. 287300; Crespo. Un viaje..., op. cit.

100. CRespo Delgado, Daniel. "La arquitectura del Museo del Prado vista por sus contemporáneos (1789-1815)”. Madrid. Revista de Arte, Historia y Geografía, 2006, 8, pp. 327-358. Sobre el edificio 
A pesar de su diversa función respecto a los mencionados palacios, nunca se olvidó que esta construcción fue promovida por las más altas instancias. Como recordó Madrazo, fue imaginada por Carlos III, emprendida por Carlos IV y restaurada por Fernando VII ${ }^{101}$. De la Corte, por tanto, surgían impulsos considerados decisivos para las bellas artes.

Según nuestros eruditos, el absolutismo no era un obstáculo para el desarrollo. El duque de Almodóvar, quien leyó la oración pública de la distribución de premios de la Real Academia de San Fernando de 1787, señaló en su adaptación al español del clásico del abate Raynal que "cuando una Nación obedece a una Monarquía absoluta, si logra gozar de buenos Soberanos, puede llamarse la más dichosa ${ }^{102}$. Para que no hubiese dudas respecto a la conveniencia del sistema que debía dirigir al país, Almodóvar subrayó que "siempre la España fue Monarquía, con sólo aquellas variaciones propias de sus diversas y respectivas circunstancias; este ha sido y es el genio, complexión y carácter de la Nación» ${ }^{103}$. Dicho carácter no le había imposibilitado su progreso; todo lo contrario.

En el discurso preliminar de las Noticias de los arquitectos... (1829), Ceán aseguró que los reinados de Felipe II y Carlos III habían supuesto el momento de mayor esplendor de la arquitectura española, entre otros motivos gracias a la medidas tomadas por esos mismos monarcas. Medidas que suponían el control y la revisión por parte de la Corte o de sus instituciones -Herrera en el siglo XVI; la Academia de San Fernando en el XVIII- de las trazas de los edificios que deseaban erigirse en el reino ${ }^{104}$. La influencia del regalismo borbónico en estas tesis resulta evidente.

Es sabido que ya entre los ilustrados, incluso entre los moderados, se emitieron censuras a la gestión política de Carlos V y Felipe $\mathrm{II}^{105}$. El propio Ponz, en una línea argumental nada original, criticó su obsesión conquistadora y bélica ${ }^{106}$. De hecho, El Escorial pronto pasó a encarnar para algunos el predicado oscurantismo

del Prado es obligada la consulta de los trabajos de Pedro Molé́n, entre los que destacamos: Proyectos y obras para el Museo del Prado: fuentes documentales para su historia. Madrid: Museo del Prado, 1996.

101. Colección lithográphica de cuadros del Rey de España el Señor Fernando VII. Madrid: Real Establecimiento Litográphico, 1826-1832.

102. Almodóvar, Pedro Jiménez de Góngora, Duque de (Eduardo Malo de Luque [anagr.]). Historia política de los establecimientos ultramarinos de las naciones europeas. Madrid: Antonio de Sancha, 1784-1790, t. II, Prólogo, p. IV. La Historia política de Almodóvar fue una adaptación de la celebérrima Histoire Philosophique et Politique des Etablessimens et du Comerse des Européens dans les deux Indes del abate Raynal. García RegueIro, Ovidio. "Ilustración" e intereses estamentales. Antagonismo entre sociedad tradicional y corrientes innovadoras en la versión española de la "Historia" de Raynal. Madrid: Universidad Complutense, 1982; Almodóvar, Pedro Jiménez de Góngora, Duque de. Constitución inglesa. Madrid: BOE, 2000. Estudio introductorio a cargo de Jesús Vallejo.

103. Almodóvar. Historia..., op. cit., t. II, Prólogo, p. VI.

104. LlagunO. Noticias..., op. cit., t. I, pp. XXXVI y XXXIX.

105. Roura Aulinas, Lluís. "Poder o glòria? La imatge de Felip II a l'època de les Llums». En Felipe II y el Mediterráneo. Madrid: Sociedad Española para la Conmemoración de los Centenarios de Carlos V y Felipe II, 1999, t. IV, pp. 501-525.

106. CRespo. Un viaje..., op. cit. 
de los Austrias ${ }^{107}$. Aunque no publicados hasta 1870, en 1822, en pleno Trienio Liberal, Ceán escribió unos muy sugestivos diálogos entre Juan de Herrera y el ingeniero Bautista Antonelli, donde arreciaron críticas a Felipe $\mathrm{II}^{108}$. Se subrayó su mezquindad y cicatería con estos artistas, responsabilizándolo de las pésimas condiciones en las que trabajaron. No deja de ser significativo cómo en estos tres diálogos se repitieron, como seguramente no se había hecho hasta la fecha en la literatura artística, palabras como nación y patria. Es más, se definieron como los resortes que movieron a dichos maestros a estudiar y progresar en las bellas artes y las ciencias. En estos diálogos, Herrera se convirtió en un patriota.

Pero esta corriente fue excepcional en nuestra historiografía artística. En los mismos diálogos de Herrera y Antonelli, Felipe II apareció como un rey con una notable formación artística y con un ejemplar criterio de elección. En una obra escrita con posterioridad, marcada por la vuelta al trono de Fernando VII, en la Historia del Arte de la Pintura (1822-1828), Ceán identificó la crisis de finales del siglo XVII con el reinado de Carlos II, si bien matizando la responsabilidad del monarca. Deslizó la idea de que la obsesión por la pintura de Felipe IV fue nociva para el país al apartarlo de las tareas de gobierno, pero lo hizo de manera enormemente cautelosa $^{109}$. La afirmación de la responsabilidad negativa de los monarcas era todavía muy problemática. La crítica a los reyes no era posible en las décadas anteriores a la plena irrupción del liberalismo; incluso la censura de la anterior dinastía tenía claros límites. La corona casi siempre apareció para ser bruñida; las bellas artes resultaron ser una de sus joyas de más rutilantes destellos.

El desarrollo económico fue otra de las razones aducidas de manera reiterada para explicar el avance de las bellas artes. Tampoco esto era demasiado original puesto que la generación ilustrada solía considerar la economía el fundamento del progreso, una fuente de donde manaba la benéfica savia que nutría al país. Desde esta convicción, Antonio Ponz contestó a quienes censuraron que en su Viaje de España (1772-1794) proporcionase tantas noticias relativas al fomento económico. Les acusó de no darse cuenta de que el fomento de la agricultura o el crecimiento de la población suponía poner las bases de la anhelada perfección de las artes. Ponz fue rotundo:

[las bellas artes] es imposible que hagan mansión entre la aridez y pobreza... Su propio nicho es la abundancia, la frondosidad y la belleza de los países, cuyos objetos excitan en los profesores ideas de placer y amenidad, con que agradar a los que contemplan sus producciones ${ }^{110}$.

107. Álvarez Junco, José. "La construcción de España». En Martínez Millán, José y Reyero, Carlos (coords.). El siglo de Carlos Vy Felipe II. La construcción de los mitos en el siglo XIX. Madrid: Sociedad Española para la Conmemoración de los Centenarios de Carlos V y Felipe II, 2002, t. I, pp. 31-49.

108. CeÁn Bermúdez, Juan Agustín. "Tres diálogos entre Juan de Herrera, arquitecto de Felipe II, y Battista Antonelli, su ingeniero, sobre las grandes obras que ejecutaron y lo mal premiados que por ellas fueron. Escritos en Madrid en 1822». En Ocios..., op. cit.

109. CEÁN. Historia..., op. cit., t. VI, p. 170.

110. Ponz. Viage..., op. cit., t. XI, I, 32. 
Según Ponz, periodos de esplendor como la Grecia clásica o la España del siglo XVI probaban que desarrollo y poder redundaban de manera positiva en las artes. Incidió en un caso especialmente sintomático: Sevilla y su extraordinaria escuela pictórica. Partiendo de nuevo de la idea de que «las bellas artes sólo se acompañan con la belleza, y la opulencia es quien las sostiene», Ponz vinculó el nacimiento y florecimiento de la escuela sevillana al liderazgo comercial de la ciudad en los siglos XVI y XVII, cuando se convirtió en el puerto de las Indias, el epicentro de los intercambios con el Nuevo Mundo. La decadencia de sus artes había corrido en paralelo a la de la propia ciudad: cuando ésta dejó de ser un centro activo y opulento, sus pinceles se marchitaron. Es más, en opinión de Ponz, los muchos y célebres escritores que abundaron en Sevilla se debían también a su pasado desarrollo. No debiera extrañarnos, por tanto, que para revivir las artes y las letras de la ciudad considerase indispensable resucitar su economía ${ }^{111}$. La abundancia y la mayor actividad que se dijo insuflaba el vigor económico en una sociedad no sólo eclosionaba en disciplinas que tenían que ver con el hacer mecánico. El buen gusto no era en absoluto ajeno, sino una de sus manifestaciones. El aliento burgués de las Luces, en este caso, parece claro.

En la Historia del Arte de la Pintura, la riqueza también fue uno de los principios recurrentes para explicar el florecimiento artístico. Ceán advirtió que podía parecer increíble el enorme número de pintores que en los siglos XVI y XVII se dieron en Holanda, una región definida como "estéril, húmeda y cenagosa", pero cabía recordar las no menores ganancias generadas por su comercio ${ }^{112}$. Los muchos pintores flamencos de ciudades como Amberes, Bruselas o Malinas los relacionó de igual modo con la abundancia de la que disfrutaron tales centros ${ }^{113}$. Sevilla, en varias ocasiones de la Historia citada como la "opulenta Sevilla", se presentó como otro ejemplo de que "los artistas no pueden existir en los pueblos que no tengan esta circunstancia». Su extraordinario plantel de maestros de los siglos XVI y XVII, las admirables consecuciones que alcanzaron no se explicarían sin «las grandes riquezas que llegaban de América a Sevilla, que era entonces el emporio del comercio de Europa y de aquella otra parte del mundo ${ }^{114}$. Ceán sostuvo que la decadencia de su escuela se había producido, precisamente, con el traslado del comercio americano al puerto de Cádiz.

En el texto que consideramos más sobresaliente de la historiografía artística española de la época, la Memoria sobre la fábrica de la Lonja de Palma de Mallorca, cuya primera publicación fue en 1812, Jovellanos convirtió este soberbio edificio gótico, levantado por y para los mercaderes, en símbolo del desarrollo comercial que vivificó el periodo más brillante de la isla. El asturiano esperaba

111. CRespo. Un viaje..., op. cit.

112. CEÁN. Historia..., op. cit., t. IV, p. 59.

113. Ibidem, t. III, pp. 76, 163 y 295.

114. Ibídem, Historia..., op. cit., t. VII, p. 112. 
que la apertura del comercio americano decretado por Carlos III restaurase la economía mallorquina y trajese una nueva "y venturosa época». Entonces la Lonja, cuya original hermosura se conservaba sin mengua, «ennoblecido más y más su destino, llevará a la posteridad el nombre de Sagrera y el de los ilustres ciudadanos que la levantaron ${ }^{115}$. Tan espléndido edificio marcaba incluso el ansiado camino de futuro.

Una sociedad ilustrada, desarrollada, estable y bien ordenada conformaba, por tanto, el contexto propicio para el progreso de las bellas artes. Ya anotamos cómo la guerra se consideró uno de sus peores obstáculos. Ponz alegó que los "cuidados de la guerra» impedían a los gobernantes proteger adecuadamente tales disciplinas, puesto que en medio de las necesidades bélicas no resultaba pertinente "pensar en estas delicadas producciones del espíritu» ${ }^{116}$. Ésta fue la razón, según Ceán, por la que Felipe V no pudo ocuparse de ellas tras llegar a España, sino sólo tras finalizar la Guerra de Sucesión. La restauración de la pintura que deseaba emprender tuvo que esperar a la consecución de la ansiada paz ${ }^{117}$. Escribiendo esto en la segunda mitad de los años 20 del siglo XIX, en plena convulsión política por la pugna entre conservadores y liberales, Ceán afirmó que los tiempos actuales volvían a probar tan triste evidencia:

Todos saben, y ahora más que nunca lo experimentamos, que las bellas artes no pueden prosperar mientras los ánimos de los artistas no gocen de la quietud y seguridad, que ellas mismas exigen ser ejercitadas con acierto $^{118}$.

No hay duda de que se refería a las tensas luchas contemporáneas entre absolutistas apostólicos, liberales radicales y moderados. Haciéndose eco de las tesis afrancesadas y moderadas, Ceán consideró la oposición entre partidos como un terrible mal y de donde dimanaban los graves problemas del país, entre ellos los que afectaban a sus producciones culturales y artísticas. De hecho, confesó haber iniciado su Historia del Arte de la Pintura para abstraerse de la dramática situación de la nación, no otra seguramente para él que la derivada del triunfo del liberalismo radical hacia 1822. Es sabido que en la Historia introdujo notas sobre la actualidad política en las que saludó con alegría la reintegración en el trono de Fernando VII por los Cien Mil Hijos de San Luis. Incluso llegó a arremeter directamente contra el gobierno constitucionalista del Trienio Liberal, tildando de impropia de un país culto la medida decretada en 1822 por la que los pintores individuos de mérito y directores de la Academia de San Fernando

115. Jovellanos. Memorias..., op. cit., p. 293. Crespo Delgado, Daniel y Domenge Mesquida, Joan. "Trazos de una naciente historia del arte: los dibujos de la Lonja de Palma para la Memoria de Jovellanos". Locus Amoenus, 2010, 10, pp. 153-168.

116. PONZ. Viage..., op. cit., t. IX, Carta Última, 26.

117. CEÁn. Historia..., op. cit., t. VI, p. 232.

118. Ibidem, t. VI, p. 220. 
contribuyesen al Estado, con un tanto por ciento de lo ganado en un año por su trabajo ${ }^{119}$.

Pero Ceán no se quedó ahí y llegó a equiparar estas contiendas a las de la sociedad medieval, a las que enfrentaron a los nobles y reyes, desangrando al país. Los débiles progresos que detectó en la pintura medieval española los atribuyó, y en no poca medida, a las luchas feudales sostenidas pertinazmente por los poderosos y descritas con detalle por los cronistas. Para que no hubiese duda de su lectura en términos de actualidad apuntilló que:

no hay enemigo más destructor ni más perjudicial a la prosperidad de las ciencias y de las bellas artes que la división de opiniones políticas. Todo lo arruina, debilita el espíritu de los que las profesan y los precipita en la ignorancia ${ }^{120}$.

Luego se consideró que la estabilidad y el buen orden anhelado, el adecuado para el progreso, lo proporcionaba un poder concentrado y absoluto, no cabiendo alientos democráticos. Valores como la libertad, que ya se encontraba en los debates de la erudición ilustrada continental, fueron ignorados casi por completo por nuestra literatura artística. En su celebérrima Historia del arte de la Antigüedad (1764), Winckelmann, cuya simpatía por los sistemas republicanos parece probada, proclamó la libertad, el peculiar régimen político griego, como una de las causas de su preeminencia en las artes ${ }^{121}$. Sin embargo, autores como Ponz o Campomanes, que se refirieron al autor alemán, o Ceán o Bosarte, quienes analizaron en algunos de sus trabajos las presuntas perfecciones alcanzadas por los antiguos, obviaron dicho principio ${ }^{122}$. Ni siquiera en los artículos publicados en la prensa periódica o en las líneas dedicadas al arte de países extranjeros se introdujeron valores característicos de la Ilustración más avanzada.

Un caso paradigmático lo proporcionarían las referencias a Inglaterra. Visitada por Ponz en 1783, el secretario de la Academia de San Fernando admiró el desarrollo que su arquitectura había experimentado en las últimas décadas y que se manifestaba en multitud de edificios, erigidos tanto en las ciudades como en el campo. Los describió prolijamente en su Viaje fuera de España (1785) y los consideró incomparables con lo realizado en cualquier otra parte del continente, siendo la punta de lanza de la arquitectura contemporánea. Atribuyó esta

119. Ibídem, t. II, p. 367.

120. Ibidem, Historia..., op. cit., t. I, p. 309.

121. Pommier, Édouard. "Winckelmann et la vision de l'Antiquité dans la France des Lumières et de la Révolution". Revue de l'Art, 1989, 83, pp. 9-20; DÉcultot, Elisabeth. Johann Joachim Winckelmann: enquête sur la genèse de l'bistoire de l'art. Paris: PUF, 2000.

122. CRespo. Un viaje..., op. cit.; WincKelmann, Johann Joachim. Historia de las artes entre los antiguos. Obra traducida del alemán al francés y de este al castellano en 1784 e ilustrado con algunas notas por Diego Antonio Rejón de Silva. Madrid: Real Academia de Bellas Artes de San Fernando, 2014. Edición de Alejandro Martínez Pérez. 
sorprendente situación, en un país cuya aportación a las bellas artes había sido menor hasta la fecha, a su extraordinario crecimiento económico, así como al patriotismo y al buen gusto de sus élites, formadas en el Grand Tour y siempre pendientes de emprender iniciativas que redundasen en el avance de la nación. A diferencia de otras plumas prestigiosas de las Luces, la especial constitución política inglesa, que reconocía y protegía diversas libertades públicas, nada tenía que ver, según Ponz, con el admirable progreso del país en general, y el de sus bellas artes y su arquitectura en particular. Es más, Ponz fue muy crítico con dichas libertades ${ }^{123}$.

En un texto de especial significación estética, en la Carta sobre la arquitectura inglesa y la llamada gótica (1805), Jovellanos analizó de manera mucho más sutil que Ponz los motivos de la contemporánea primacía inglesa en la arquitectura. Sin embargo, Jovellanos, que desgranó en esta obra escrita durante su encierro en Bellver principios estéticos renovadores, tampoco hizo referencia a las libertades amparadas por la Constitución inglesa ${ }^{124}$. De nuevo, la libertad era olvidada.

Como apuntamos, la prensa periódica, un género que con todos los matices que se quieran y deban hacerse fue en general más abierto, no aportó nada especialmente destacado a la hora de narrar el progreso de lo artístico. No se contó con ninguna publicación monográfica o especializada, pero las bellas artes hicieron su aparición en múltiples papeles periódicos y con textos muy diversos y de gran interés. Encontramos críticas de las exposiciones de la Academia de San Fernando y de nuevas construcciones, reflexiones estéticas o sobre el estado de las artes contemporáneas; ni siquiera el pasado quedó al margen y en la prensa se publicaron interesantes aportaciones histórico-artísticas ${ }^{125}$. No obstante, no sirvieron para introducir otros argumentos más allá de los comunes y moderados, que explicasen el avance y la decadencia de las bellas artes.

Hay que advertir, como contrapunto, que durante los periodos en los que el liberalismo se hizo con el poder llegaron a aflorar otras sendas. Vimos como en los diálogos entre Herrera y Antonelli -escritos en 1822 por Ceán si bien publicados mucho más tarde- se criticó la cicatería de un rey al no haber recompensado justamente a estos dos maestros, caracterizados como patriotas que habían trabajado

123. CRespo Delgado, Daniel. "Il giro del mondo. El Viage fuera de España (1785) de Antonio Ponz". Reales Sitios, 2002, 152, pp. 64-82; Bolufer Peruga, Mónica. "Una mirada por Europa en el Siglo de las Luces: Antonio Ponz y su Viaje fuera de España». En PONZ, Antonio. Viaje fuera de España. Alicante: Universidad de Alicante, 2007, pp. 13-175.

124. Crespo y Domenge. Jovellanos..., op. cit.

125. CRESPO DelgAdo, Daniel. "De arquitectura y arquitectos en los papeles periódicos españoles anteriores al 1808». Boletín de Arte, 2004, 25, pp. 335-371; ibídem, "La arquitectura...", op. cit.; "Diario... ", op. cit.; "Lectores y noticias sobre bellas artes en los papeles periódicos españoles de la Ilustración». En Mestre, José María; DíAz, Antonio y Romero, Alberto (eds.). Francisco Mariano Nipho. El nacimiento de la prensa y de la crítica literaria periodística en la España del siglo XVIII. Alcañiz, Madrid: Instituto de Estudios Humanísticos, CSIC, 2015, pp. 199-215. 
por el país sólo por su desinteresado amor hacia el mismo. Pero el texto más sorprendente en esta línea es un manuscrito sobre el grabado iniciado por Ceán a finales de 1819. Nunca se imprimió y nos ha llegado parcialmente ${ }^{126}$. Sin embargo, conservamos la introducción a la historia de la evolución de las diferentes escuelas europeas de grabado, siendo especialmente interesantes la inglesa y la española. La primera porque Ceán puso en directa relación el desarrollo alcanzado durante el siglo XVIII por el grabado inglés - de hecho el de la nación en su conjuntocon su "admirable constitución, milagro del entendimiento humano" puesto que garantizaba la "seguridad y libertad» de sus ciudadanos. Vale la pena transcribir su último párrafo dedicado a esta escuela, una elocuente proclama liberal:

Sin libertad no prosperan las artes, y sin artes no puede haber riqueza nacional. Luego para que una nación sea rica necesita ser artista, y para llegar a serlo es indispensable la libertad, que solamente le puede dar una prudente y justa Constitución.

Según Ceán, la escuela española se encontraba en una situación más ventajosa incluso que la inglesa a finales del XVII, justo antes de darse su modélico ordenamiento jurídico. Por tanto, Ceán se imaginó que con la reciente aprobación de la Constitución española, que «restituye al español sus derechos y su libertad», el "genio nacional" se elevaría a cotas antes inimaginables ${ }^{127}$. En este caso, por tanto, sí se predicó de la libertad un decisivo papel en el desarrollo de las artes. Un camino que como vimos líneas atrás Ceán acabó abandonando.

Como conclusión, apuntemos que la historia del arte se mantuvo en las coordenadas del pensamiento ilustrado moderado. En parte porque las condiciones políticas no permitieron una discusión pública de otras vías, que fueron silenciadas o, como en el caso de Ceán, autocensuradas. No obstante, las bellas artes se consolidaron como rasgo de lo histórico, como uno de sus fenómenos privilegiados. Desde este punto de vista, el significado -y en especial el sentido público- de las artes y de la arquitectura debía redefinirse. En tales disciplinas se desvelaba el pulso y el punto donde se encontraba una sociedad. De hecho, algunos artistas también empezaron a asumir su nuevo rol. Por consiguiente, si bien la historia del arte de la Ilustración en España no se trazó desde principios revolucionarios, el lugar hacia el que proyectó las bellas artes, su manera de entenderlas, sí resultaba inédito y un aspecto fundamental en su desarrollo posterior.

126. Santiago PÁez, Elena. El gabinete de estampas de Ceán Bermúdez. Dibujos, estampas y manuscritos de la Biblioteca Nacional. Gijón: Museo-casa natal de Jovellanos, 1997.

127. Biblioteca Nacional de España, Mss. 21458 (1). 